\title{
High-Resolution Dynamical Downscaling of ERA-Interim Using the WRF Regional Climate Model for the Area of Poland. Part 2: Model Performance with Respect to Automatically Derived Circulation Types
}

\author{
Hanna Ojrzyńska, ${ }^{1}$ Maciej Kryza,,${ }^{1}$ Kinga Wałaszek, ${ }^{1}$ Mariusz Szymanowski, ${ }^{2}$ Małgorzata Werner,,${ }^{1,3}$ and \\ AnTHONY J. DORE ${ }^{4}$
}

\begin{abstract}
This paper presents the application of the high-resolution WRF model data for the automatic classification of the atmospheric circulation types and the evaluation of the model results for daily rainfall and air temperatures. The WRF model evaluation is performed by comparison with measurements and gridded data (E-OBS). The study is focused on the area of Poland and covers the 1981-2010 period, for which the WRF model has been run using three nested domains with spatial resolution of $45 \mathrm{~km} \times 45 \mathrm{~km}, 15 \mathrm{~km} \times 15 \mathrm{~km}$ and $5 \mathrm{~km} \times 5 \mathrm{~km}$. For the model evaluation, we have used the data from the innermost domain, and data from the second domain were used for circulation typology. According to the circulation type analysis, the anticyclonic types (AAD and $\mathrm{AAW}$ ) are the most frequent. The WRF model is able to reproduce the daily air temperatures and the error statistics are better, compared with the interpolation-based gridded dataset. The high-resolution WRF model shows a higher spatial variability of both air temperature and rainfall, compared with the E-OBS dataset. For the rainfall, the WRF model, in general, overestimates the measured values. The model performance shows a seasonal pattern and is also dependent on the atmospheric circulation type, especially for daily rainfall.
\end{abstract}

Key words: Atmospheric circulation, rainfall, air temperature, WRF, dynamical downscaling, ERA-Interim, circulation types.

\section{Introduction}

Spatial meteorological information is a key element in various environmental studies, including air pollution, hydrology (JEZIORSKA and NIEDZIELSKI 2015, this issue) and wind energy production (BADGER et al. 2014; MendeZ et al. 2014). This information can be provided in various ways, including GIS-based interpolation (SzYMANOwSKI et al. 2013) and statistical or dynamical downscaling (GIORGI and BAtES 1989; Lo et al. 2008; CZERNECKI 2013). There is also a combined approach, named statistical-dynamical downscaling, which has also gained importance in climate research in recent years. Statistical-dynamical downscaling combines the benefit of both techniques and was presented, e.g. by FuENTES and Heimann (2000) and Reyers et al. (2015). The performance of these approaches is also evaluated in different ways, by comparing the results with available measurements and with other reference spatial data, including gridded information.

Atmospheric circulation plays a major role in daily, seasonal and spatial distribution of weatherrelated parameters, including air temperature and rainfall. Poland (Central Europe) is notable for transitional characteristics of climate, from maritime in the west to more continental in the east, and this region is the focus of the current study. There are many studies that link the local meteorological features, usually based on station measurements, with large-scale circulation patterns, classified into different groups using various approaches. For example, OsuchowsKa-Klein (1992) and NiEdźwiedź (1981) analysed the relation between the air temperature and
Institute of Geography and Regional Development, Wrocław University, ul. Kosiby 8, 51-621 Wrocław, Poland. E-mail: maciej.kryza@uwr.edu.pl

2 Department of Geoinformatics and Cartography, Institute of Geography and Regional Development, Wrocław University, pl. Uniwersytecki 1, 50-137 Wrocław, Poland.

3 National Pollen and Aerobiology Research Unit, University of Worcester, Henwick Grove, Worcester WR2 6AJ, UK.

4 Centre for Ecology and Hydrology, Bush Estate, Penicuik, Midlothian EH26 0QB, UK. 
atmospheric circulation using a classification based on sea level pressure, while other authors proved that the spatial variability of air temperature and precipitation is highly correlated with the geopotential height at upper isobaric levels (WIBIG 1991, 2001; KOżUCHOwski et al. 1992). Ustrnul (2000) and UstRnUl et al. (2010) have shown that a circulation type with anticyclonic ridge forms the most favourable conditions for the high air temperatures in summer. For winter, anticyclonic types with easterly flows are favourable for extremely low air temperatures. Synoptic conditions favourable to frosty, freezing and severe freezing days for Poland were analysed by BIELEC-BáKOWSKA and ŁUPIKASZA (2009) and Ustrnul et al. (2014). Bednorz (2012) and BEDNORZ and Wibig (2008) showed that the atmospheric circulation has a large impact on intense thaws and snow conditions. ŁuPIKASZA (2010) analysed the relationship between atmospheric circulation and high daily precipitation in Poland, using various methods of classifications of circulation types. NiedźwIedź (1981), Twardosz and NiedźwIEdź (2001) and Twardosz et al. (2011) analysed the role of synoptic circulation patterns on daily rainfall in south-west Poland for a long period and found that the advection of air masses from the west and cyclonic troughs are the most favourable to precipitation events. Finally, the circulation patterns were used during the construction of the GIS-based maps of meteorological elements spatial variability (UsTRNUL 2006; OJRZYŃSKA 2015).

A detailed weather and climate analysis based on various data sets should be supported by the analysis of atmospheric circulation. There are different approaches to the classification of circulation types, and several of these methods were applied for the study area addressed in this paper (e.g. LITYNSKI 1969; NiedźwIedŹ 1981; OsuchowsKa-KLeIN 1978; GeRStengarbe et al. 1993; UstrnUl 1997; WiBig 2001; Huth et al. 2008; Piotrowski 2009; WoyciechowsKA and Ustrnul 2011; Bednorz 2012). The results of the 733 COST action Harmonisation and applications of weather type classification for European Regions (cost733.met.no/FinalEvent.html) emphasize that high spatial variability of atmospheric circulation patterns preclude a general and universal method for circulation type classification and justifies the development and application of regional methodology. A long time series of meteorological data provides the opportunity to apply complex classification schemes with large numbers of distinct types. This kind of classifications could be troublesome in statistical analysis and practical applications, but also more circulation types allow a more detailed weather description in case studies. In this study, we develop an approach similar to the Objective Weather Type Classification (Die objective Wetterlagenklassifikation) of the German Weather Service (BISSOLLI AND DitTmann 2001), which, apart from e.g. cyclonality and direction of the air masses advection, utilizes information on the humidity of the air. A modification of the original classification scheme described by Bissolli and DitTmann (2001) was previously successfully applied for the Sudetes Mountains (SW Poland) and their foreland (OJRZYŃSKA 2015), using coarse resolution gridded meteorological data. Here, the objective classification scheme is fed with the WRF-derived meteorological information, available at high spatial resolution. This is a novelty, as previous studies used coarse resolution meteorological information for classification of circulation types, coming from global reanalysis databases like NCEP or ERA (Ustrnul 1997; Bissolli AND DitTMANN 2001; Piotrowski 2009; Woyciechowska and Ustrnul 2011; OJRZYŃSKA 2015).

In the first part of this twin paper (KRYZA et al. 2016), we have evaluated the results of the ERAInterim dynamical downscaling with the Weather Research and Forecasting (WRF) model for the period 1981-2010 using 3-hourly measurements of air temperature, humidity and wind speed and direction. Here, the focus is on evaluation of daily rainfall and air temperature for the same period, with the context of synoptic situation. Earlier reports by JIMÉNEZ et al. (2013) suggest that the model performance might rely on the synoptic situation, and their analysis was focused on wind condition for complex terrain.

In this work, we first describe and apply a method for automatic classification of the circulation types (ACCT) in Poland and then apply the method to the extended period of 1981-2010 with WRF model data. Secondly, we compare the WRF model for daily rainfall and air temperature with respect to the circulation types derived by application of the ACCT 
method. The analysis of the regional dynamical downscaling with the WRF model is complemented by comparison with spatial data obtained through a geostatistical (spatial interpolation) method. This spatial comparison is also performed with respect to the circulation type, to assess if the model performance changes with the atmospheric circulation pattern.

\section{Data and Methods}

\subsection{The WRF Model}

The details of the WRF model (SKamarock et al. 2008) configuration are provided in the first part of this twin paper (KRYZA et al. 2016). Here, we only provide some important remarks on the model configuration. The model has been run for a 30-year long period of 1981-2010, using ERA-Interim data as initial and boundary conditions. The model was applied for three one-way nested domains: d01 (45 km $\times 45 \mathrm{~km}$ grid for Europe), d02 $(15 \mathrm{~km} \times 15 \mathrm{~km}$ grid for Central Europe) and d03 ( $5 \mathrm{~km} \times 5 \mathrm{~km}$ grid for Poland). In this study, we compare the measurements with the results from the innermost domain (d03) covering Poland with a $5 \mathrm{~km} \times 5 \mathrm{~km}$ grid resolution, and the $\mathrm{d} 02$ results are used for classification of the circulation types. The model results are available for every $3 \mathrm{~h}$, and the daily mean air temperature is calculated by averaging all time frames available for a given day. The WRF model rainfall is available for every $3 \mathrm{~h}$ as accumulated precipitation and was recalculated into daily sums. The same time spans (6 UTC-6 UTC) were used both for the model data and the measurements.

\subsection{Calculation of Circulation Types}

The methodology of classification refers to the assumptions of "Die objective Wetterlagenklassifikation" (Bissolli and Dittmann 2001), modified according to OJRZYŃSKA (2015). One circulation type for each day is determined, using the daily meteorological data available for the domain $\mathrm{d} 02$. Four criteria of the classification are calculated individually for every grid cell of the model domain. Each of the criteria results in two to five different types. The domain-wide type of the particular criterion is calculated as the mode grid cell type within the model domain. The final circulation types (40) are composed of types of classification criteria in the following order: direction of advection (characters in positions 1-2 in type name), cyclonality at $825 \mathrm{hPa}$ (position 3), cyclonality at $500 \mathrm{hPa}$ (position 4), and humidity type (position 5; Fig. 1). The algorithm was applied here using the WRF d02 meteorological data, with $15 \mathrm{~km} \times 15 \mathrm{~km}$ spatial resolution, and the calendar of atmospheric circulation types for the area of Poland for the years 1981-2010 was prepared. The classification scheme applied here utilizes the following meteorological information:

\subsubsection{Direction of Advection}

The direction of advection is calculated directly from the $\mathrm{u}$ and $\mathrm{v}$ wind components, provided by the WRF model for $700 \mathrm{hPa}$ isobaric level. If the wind speed exceeds $2 \mathrm{~m} \mathrm{~s}^{-1}$, the wind direction for the analysed grid cell is assigned, using four main directions: NE, NW, SE, SW. Otherwise, if the wind speed is below the threshold value, the $\mathrm{XX}$ class is assigned to the grid cell. The dominant wind direction for the entire domain is the one that occurs for more than $50 \%$ of the grid cells in this domain. If there is no prevailing wind direction for the area, the final type of criterion "direction of advection" is classified as XX.

\subsubsection{Cyclonality for 825 (Lower) and 500 (Upper) Isobaric Level}

Cyclonality is calculated as an approximated value of $\nabla^{2} \phi$, where $\nabla$ is the nabla operator and $\phi$ is a value of the geopotential. Cyclonality is calculated separately for the 500 and $825 \mathrm{hPa}$ isobaric levels. A positive value of $\nabla^{2} \phi$ is classified for the cyclonic type (C), and negative for the anticyclonic (A) type. The calculation of grid cell cyclonality is a two-step procedure, based on the $3 \times 3$ grid neighbourhood. In the first step, every grid cell from a given neighbourhood is multiplied by value 1 , while the analysed grid cell (centre of a given $3 \times 3$ 


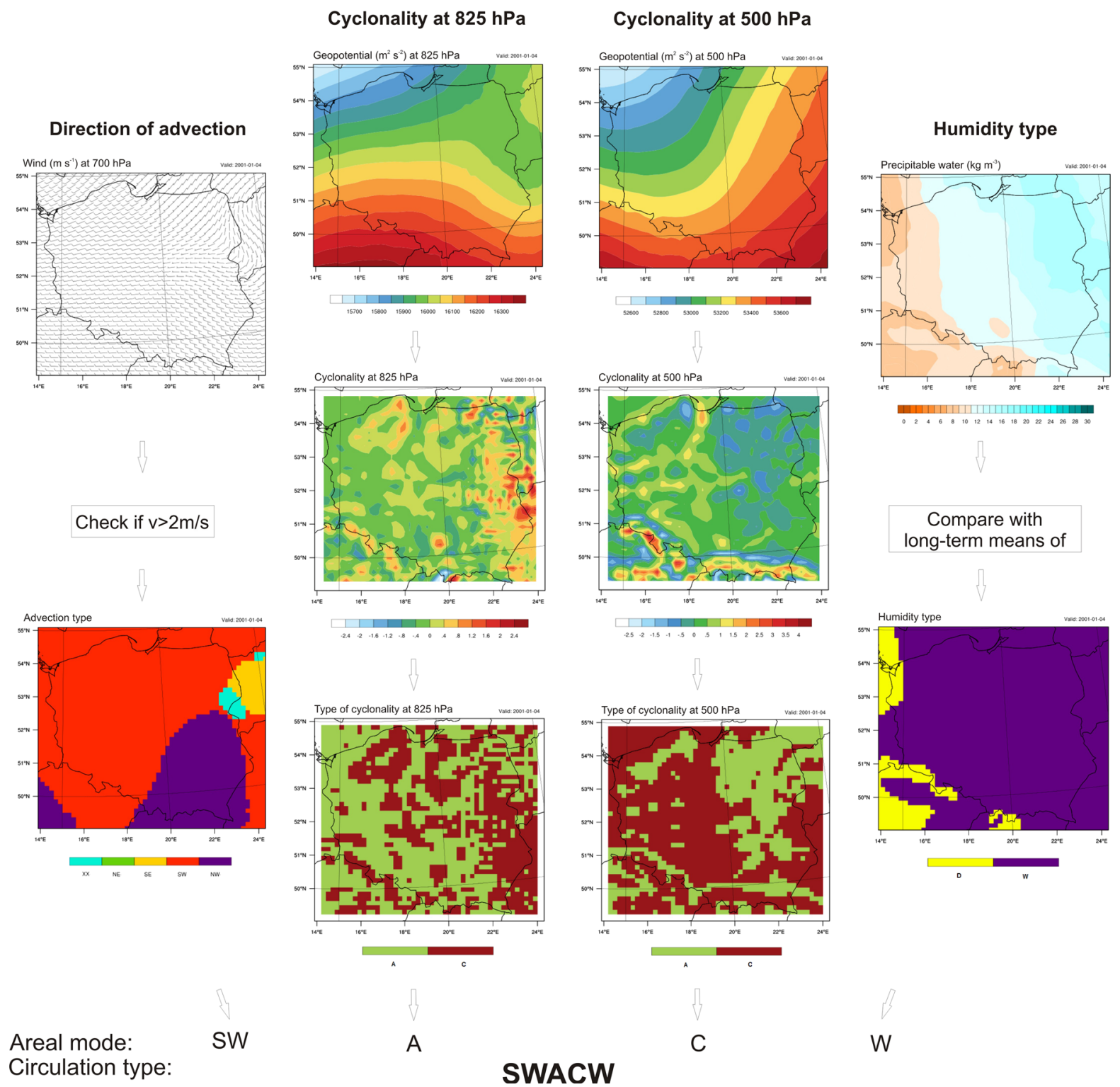

Figure 1

Circulation type classification scheme-real case for 01.04. 2001. The SWACW acronym, used here as an example, stands for: $S W$ advection direction from south-west, $A$ anticyclonic type at $825 \mathrm{hPa}, C$ cyclonic type for $500 \mathrm{hPa}, W$ wet type according to humidity-type class

neighbourhood) is multiplied by -8 . In the second step, the mean value from all nine grid cells is calculated. The result is attributed to the analysed grid as an approximate value of $\nabla^{2} \phi$. The calculation of $\nabla^{2} \phi$ is preceded by the generalization of the geopotential, which is averaged using a low-pass filter with size $3 \times 3$ grid cells.

\subsubsection{Humidity Type}

The humidity type for each grid cells is calculated as a result of subtracting the daily mean value of tropospheric precipitable water (PW) and the suitable areal long-term monthly mean of PW. A positive value of the difference is classified for wet (W) type 
and negative for dry type (D). The long-term mean PW is calculated using the WRF model data for the d02 domain.

An automatic tool for the circulation type classification took a form of script, prepared using the NCAR Command Language (NCL Software, Version $6.1 .2,2013)$. The script reads sequential netCDF files, which contain the outputs from the WRF model. The above-mentioned meteorological information, needed to determine the circulation type, is calculated for each grid cell and classified according to the classification criteria. The atmospheric circulation type is determined by the combination of the four classification criteria described above (direction of advection, lower and upper cyclonality and humidity type). This method allows for easy grouping of the detailed classification and reduction of particular classification criteria. This characteristic was utilized for the results of this study. The algorithm is flexible in terms of, e.g. the incorporation of additional meteorological parameters and can be applied for other areas and the WRF model configuration (e.g. in terms of spatial extent and grid resolution).

\subsection{Meteorological Data for the WRF Model Evaluation}

In this work, first we compare the $5 \mathrm{~km} \times 5 \mathrm{~km}$ WRF model results with the meteorological measurements of daily rainfall and daily mean air temperature, gathered at 66 synoptic stations in Poland for the 1981-2010 period. For comparison, we used the WRF model domain d03 data from a grid cell, in which the measuring site is located. It should be noted here that we used the area averages (WRF model grid cell) and point values (measuring sites) in this work. The spatial distribution of the measurement sites is presented in the first part of this twin paper (please see Fig. 1 at KRYZA et al. 2016). Secondly, we compare the WRF model results with the gridded meteorological information available for Europe and described by HAYLOCK et al. (2008).

The European land-only daily high-resolution gridded data (E-OBS; HAYLOCK et al. 2008) for daily rainfall and daily mean air temperature are available for all Europe with $0.25^{\circ} \times 0.25^{\circ}$ spatial resolution.
This dataset was developed by three-step spatial interpolation. First, the monthly mean values are interpolated with thin-plate splines. Second, the anomalies with regard to the monthly mean are interpolated using the kriging algorithm. The final map is calculated by applying the interpolated anomaly to the interpolated monthly mean (HAYLOCK et al. 2008). In this work we used E-OBS data version 10.0.

\subsection{The WRF Model Evaluation}

The WRF model results are compared with the measurements of the rainfall and daily mean air temperatures. The WRF modelled rainfall and air temperature were extracted for the nearest grids where the synoptic stations are located and compared with the station measurements. A grid-to-point comparison is performed. In the same way, the E-OBS database is compared with the measurements. This is done to assess the differences between these two approaches that provide the spatial climatological information: dynamical regional climate model and geostatistical method, and to address the uncertainty related to each dataset. The model error is calculated as the difference between the modelled (by WRF or from E-OBS) and the observed value and the results are summarized using three error statistics:

- Mean error $(M E)$ calculated as an arithmetic mean from the model error for the air temperature in ${ }^{\circ} \mathrm{C}$. A positive value of ME suggests a tendency for overestimation, while a negative value suggests underestimation of the air temperature by the model. For the rainfall, ME is given in percent, with the values $>100 \%$ showing overestimation of rainfall and $<100 \%$ showing underestimation.

- Mean absolute error (MAE) calculated as the mean value of the absolute model error. The units are ${ }^{\circ} \mathrm{C}$ for the air temperature and $\mathrm{mm} /$ day for rainfall.

- Index of agreement (IOA) calculated using the formula proposed by EMERY et al. (2001), as a standardized measure of the degree of model prediction error. Details for IOA are provided in part 1 of this paper. The values vary between 0 (no agreement) and 1 (perfect match). IOA is unitless. 
The error statistics are calculated using the data from all available stations and for the entire study period, each month and for each determined groups of circulation types. Histograms and the quantilequantile plots are provided both for the WRF and E-OBS comparison with the measurements. The WRF and E-OBS are also compared spatially for long-term periods. Additionally, the IOA statistic was calculated for each grid separately for selected groups of atmospheric circulation types to give an insight into spatial differences between the WRF and the E-OBS datasets.

Similar to the approach used for the WRF model evaluation, the rainfall and air temperature values from E-OBS datasets were extracted for the grid in which the meteorological stations were located. It must be emphasised that the E-OBS database is based on the same measurements that are used here to evaluate the results of the WRF model and, therefore, should show very similar values as the measurements. However, because of the relatively coarse grid of $0.25^{\circ}$, there might be some issues related with spatial averaging and reduction of the extremes, which is one of the key points of this work. This includes, among others, averaging of the extreme values, both for air temperature and rainfall (WIBIG et al. 2014). Additionally, for rainfall, the coarse resolution of the E-OBS database makes it less prone to incorrect spatial allocation of rainfall. The quantification of the differences between the E-OBS data and the measurements is important, because the E-OBS is used later in this work for the WRF model spatial evaluation.

The spatial distribution of the long-term mean values of rainfall and air temperatures was calculated with the WRF and E-OBS data and compared, using the original spatial resolutions of both datasets. This was done to show the value added by the higher spatial resolution of the WRF model. Secondly, we aggregated the WRF model data to the coarser E-OBS grid, and for each common grid cell we calculated the index of agreement and mean error statistics. This was possible, because for the entire period and each grid cell, time series of the WRF and E-OBS meteorological information was available. The IOA and ME were calculated for selected types of atmospheric circulation and presented as maps.

\section{Results}

The results are organized as follows. First, the general comparison of the WRF and E-OBS data with measurements is presented, including spatial comparison of the WRF and E-OBS data. Both datasets are also compared spatially, using the source spatial resolutions of WRF and E-OBS. Secondly, the information on the circulation types and frequency is provided. Finally, the WRF model and E-OBS performance are summarized with respect to the circulation types, and spatial distribution of the rainfall and air temperature, calculated with these two sources, is compared, using the common E-OBS spatial resolution.

\subsection{WRF and E-OBS Comparison with Meteorological Measurements}

Comparison of the WRF and E-OBS performance for the entire 1981-2010 period is summarized in Fig. 2 for the air temperature and rainfall. For the air temperature, both WRF and E-OBS databases have a small positive bias if the entire period and all months are considered. However, if the seasonal performance is analysed, ME changes significantly for WRF, with negative values in winter months and the highest positive values for autumn. The seasonal changes in E-OBS ME are smaller. There is also a seasonal pattern in MAE, both for WRF and E-OBS. For WRF, MAE is the highest for winter and autumn, while for E-OBS there is also a secondary maximum in summer. Noticeably, the MAE is significantly smaller for WRF, compared with E-OBS, for all months. The WRF model performance is also better in terms of IOA, which is higher when compared with E-OBS for all months of the study period. The differences in IOA are especially large for the summer months. The better agreement of the WRF model in terms of MAE and IOA, compared with E-OBS, shows the strength of the dynamical downscaling approach for providing longterm meteorological information, even before applying the bias correction techniques.

For the rainfall, the E-OBS is in closer agreement with the measurements in terms of all three statistics considered. The WRF model significantly overestimates the observed rainfall, while the 

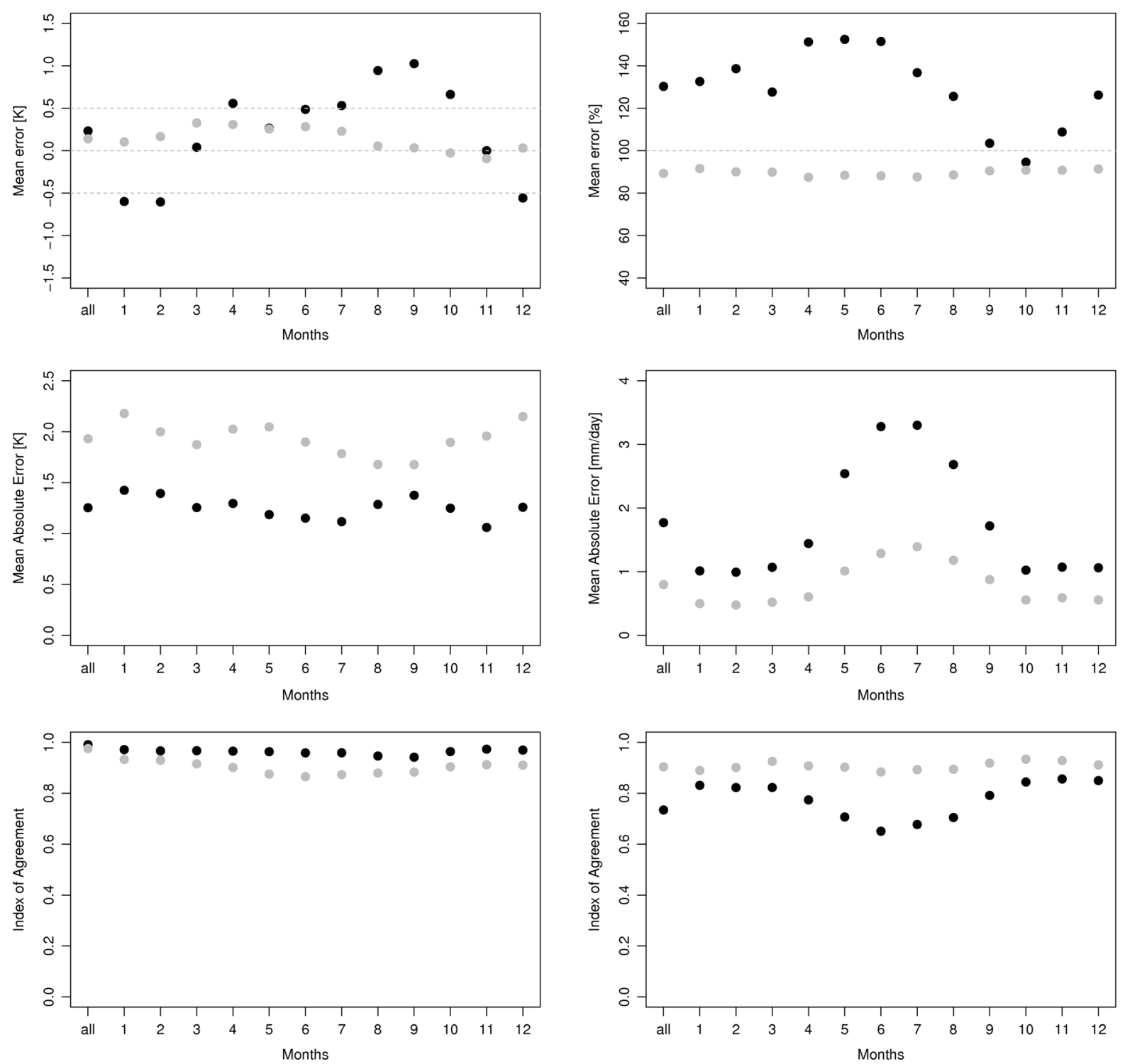

Figure 2

Summary of the WRF (black points) and E-OBS (grey points) error statistics for daily air temperature (left column) and rainfall (right) for the 1981-2010 period (all) and each month

E-OBS gridded values are slightly underestimated. There is also a clear seasonal pattern in the WRF model performance for rainfall. The largest differences between the WRF modelled and the observed daily precipitation are for summer months, when the convective rainfall dominates the total precipitation. For this season, local, intensive rainfall episodes may contribute to the majority of the monthly precipitation sum, and these events are likely to be missed or shifted both in time and space by WRF because of its local character.

The histograms of the daily $2 \mathrm{~m}$ air temperatures for the period 1981-2010, calculated with observations, WRF and E-OBS data, are presented in Fig. 3 for each season separately: winter (December-February, DJF), spring (March-May, MAM), summer (June-August, JJA) and fall (September-November, SON). The E-OBS data reproduce the air 

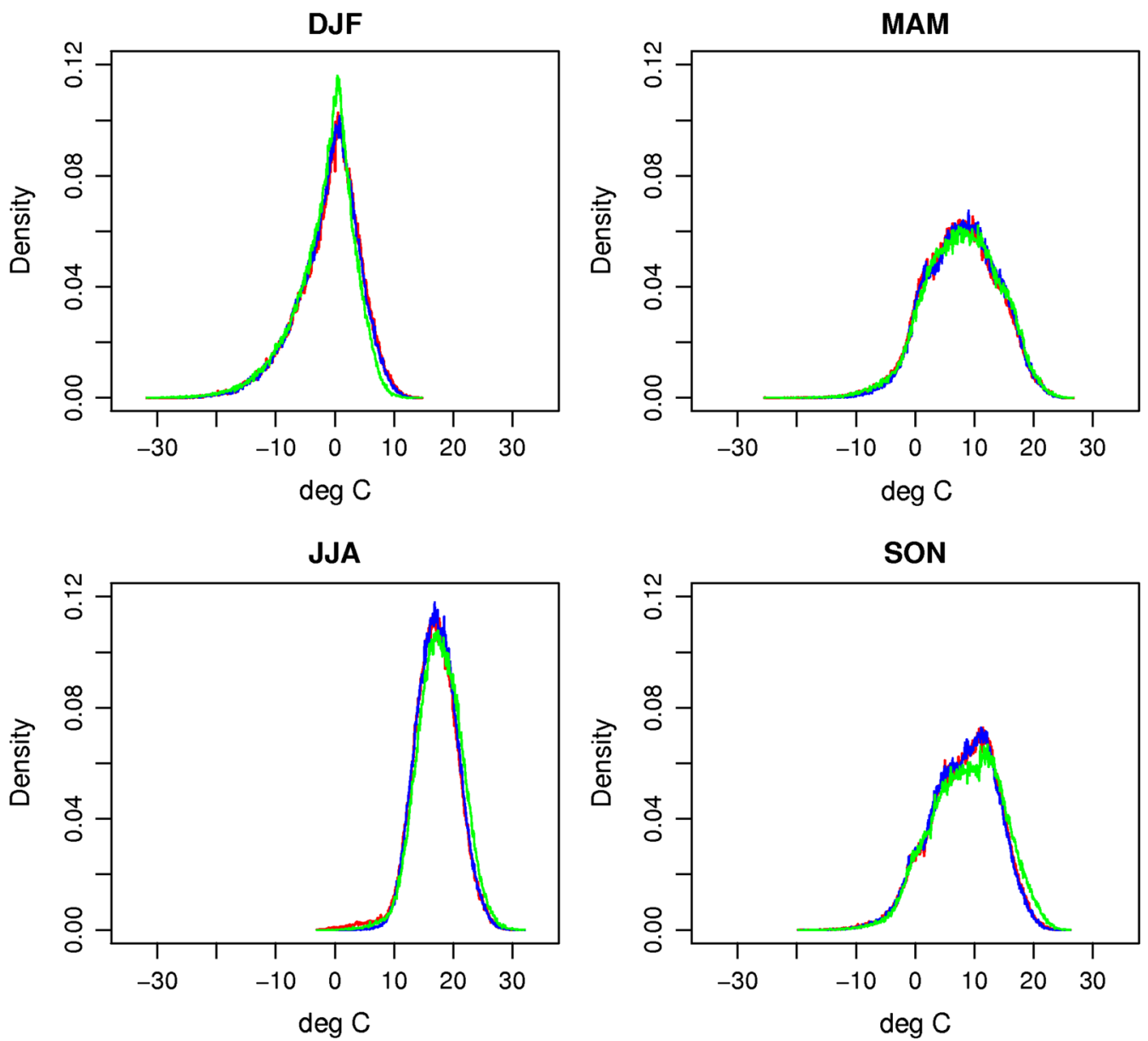

Figure 3

Histograms of daily mean air temperatures observed (red) from E-OBS (blue) and WRF (green)

temperatures very well. The WRF modelled air temperature is shifted towards cold values for December-February, which is in agreement with the ME plot shown in Fig. 2. For spring (March-May), all three sources are in close agreement, with slightly lower frequencies of air temperatures close to $8-9{ }^{\circ} \mathrm{C}$ for the WRF model. For summer (June-August) and fall (September-November), the WRF air temperature is shifted towards warm values. For all seasons, the WRF model reproduces the minimum observed air temperatures better than E-OBS. This might be linked with the higher spatial resolution of the WRF model. The highest air temperatures are overestimated except for winter (Fig. 3).

Similar features are shown if the modelled quantiles are plotted against the observed quantiles
(Fig. 4). For WRF, higher quantiles are overestimated for all seasons except winter. Low quantiles are well reproduced by WRF for all seasons.

The frequency and intensity of the precipitation events are addressed with the observed, WRF and E-OBS rainfall distribution, presented in histograms (Fig. 5). The WRF model fails to reproduce the lower end of the spectrum, with lower frequencies for all the seasons, except for autumn. The E-OBS reproduces the lower values and no rainfall days well for all the seasons. The WRF model shows a considerably lower number of cases with no rain. For rainfall in the range from 0.2 to $0.5 \mathrm{~mm}$, the WRF model is closer to the measurements compared to E-OBS. The WRF model overestimates the daily rainfall, especially the high values, for all the seasons, except for 

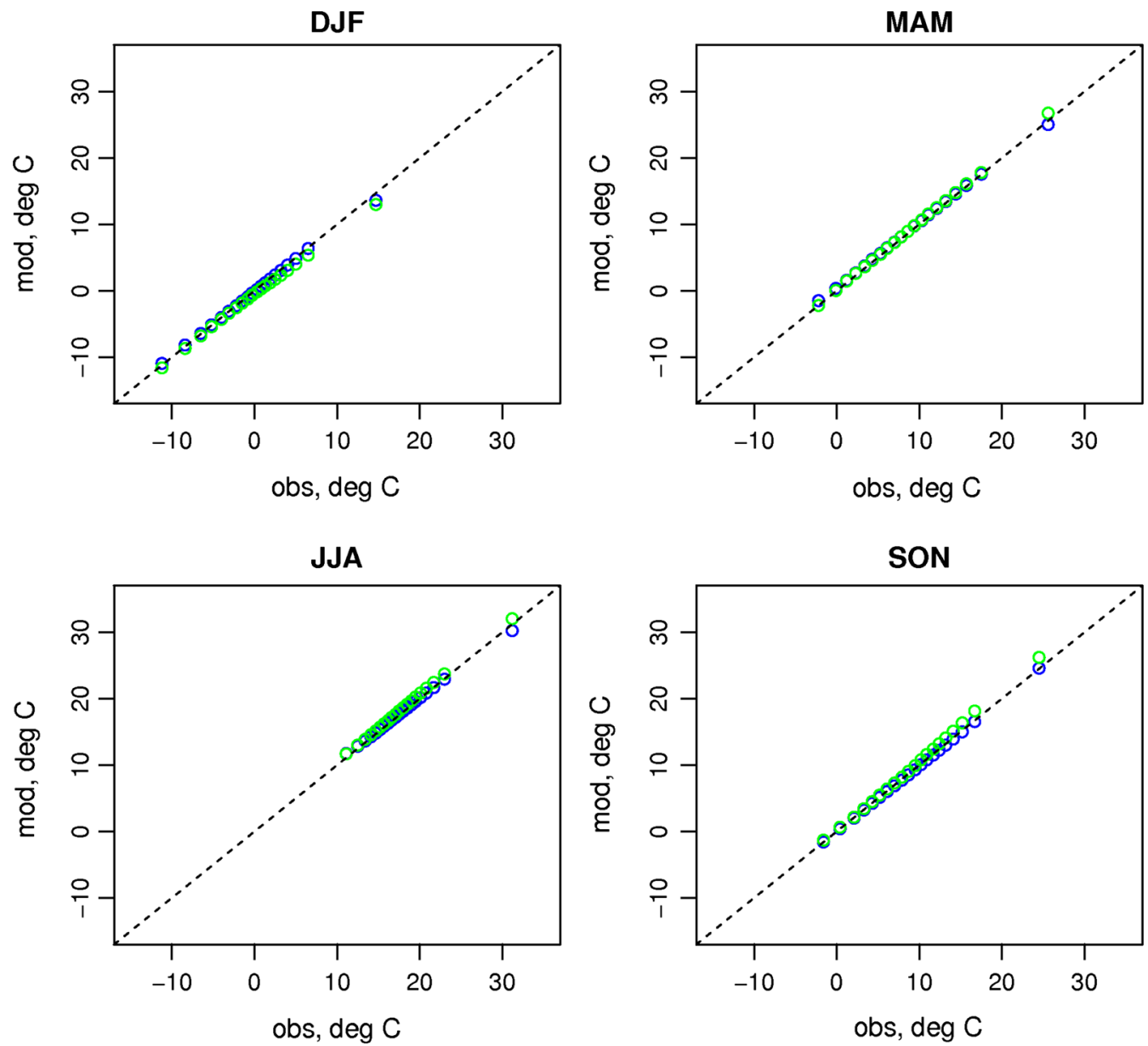

Figure 4

Quantiles (from 0.05 to 1 in steps of 0.05 ) for daily air temperature at $2 \mathrm{~m}$ for E-OBS (blue) and WRF (green). Mod is for modelled (WRF and E-OBS, $y$ axis) and obs is for observed values ( $x$ axis)

autumn (Fig. 6). The E-OBS, on the contrary, underestimates the values, which is the largest for summer and autumn.

The spatial patterns of the mean monthly air temperature and rainfall sums, calculated with the WRF and E-OBS gridded data, are presented in Figs. 7 and 8 . There is a large spatial variability in the WRF-based maps, both for the air temperature and rainfall. This is related to the significantly higher spatial resolution of the WRF data. For the air temperature, both WRF and E-OBS show similar spatial patterns. The grid-to-grid correlation coefficient is 0.94 for January and 0.87 for July. The WRF model shows higher values of the air temperatures, if summarized for the entire model domain, with the mean grid-to-grid difference at 0.26 and 1.28 for January and July, respectively. Some features, e.g. warm areas of the cities, are missing entirely in the E-OBS map.

For the rainfall, grid-to-grid correlations are smaller, and are close to 0.5 , both for January and July. The WRF maps also show higher rainfall values, compared to E-OBS, with mean differences of 14 and $41 \mathrm{~mm}$ for January and July, respectively. Both WRF and E-OBS show the highest rainfall for the mountainous areas in the south. However, the second area of increased rainfall, located in northern Poland, is shifted westward in the E-OBS maps, when compared with WRF. This is both for January and July. 
DJF

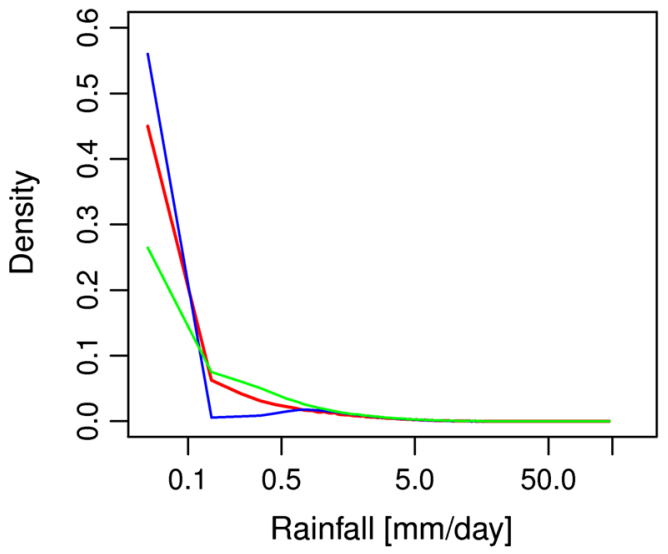

JJA

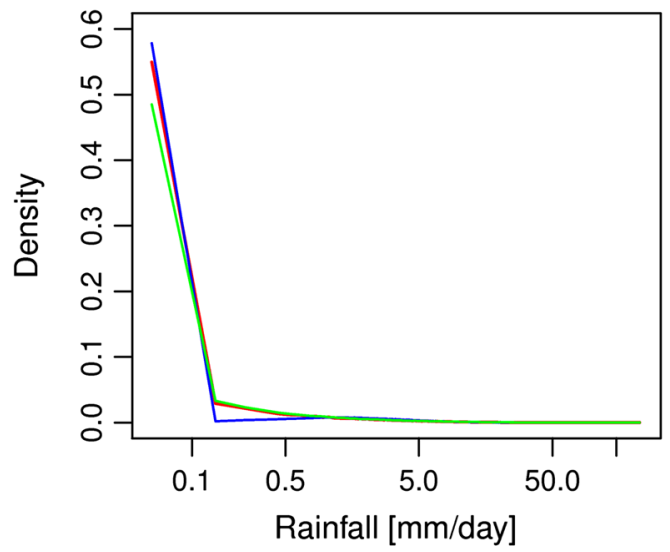

MAM

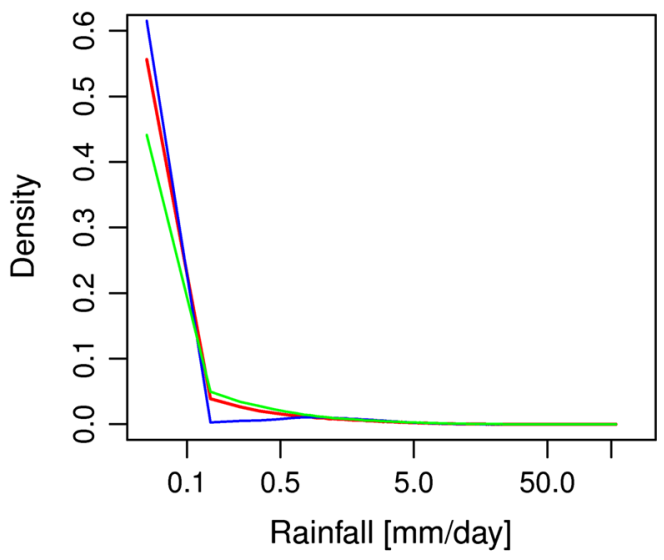

SON

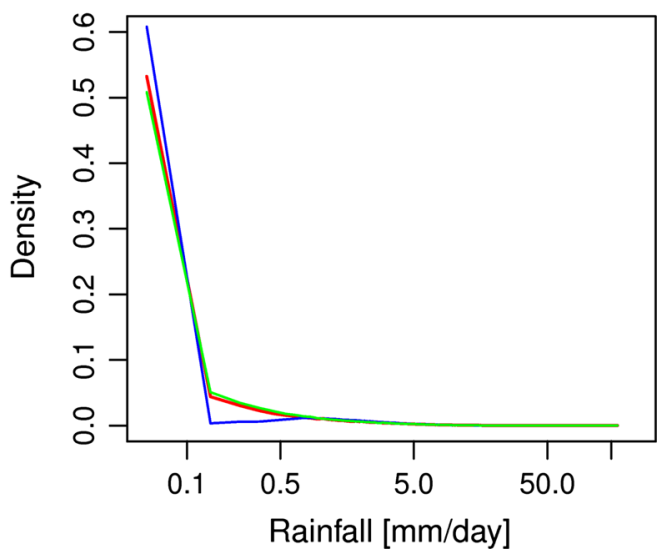

Figure 5

Histograms of daily rainfall: observed (red), from E-OBS (blue) and WRF (green)

\subsection{Circulation Types Analysis}

The circulation types classification applied in this study resulted in 40 distinct circulation types. There are seven most frequent types, with frequency exceeding $4 \%$ in the years 1981-2010, mainly anticyclonic: SWAAW, SWAAD, NWAAW, NWAAD, NEAAD and NWACD, NWCCD and SWCAW (Fig. 9). The next four most frequent types (2-4\%) are characterised with advection from the SW sector: SWACD, SWACW, SWCCD and SWCCW. The least frequent circulation types are those of the XX sector and some types with the advection from sectors NE (NEACW, NECAD, NECAW) and SE (SEACD, SEACW, SECAD). To assure the meaningful statistical analysis of the WRF model performance for rainfall and air temperature regarding the circulation types, the least frequent types were aggregated for further analysis. Finally, nine groups of various circulation types were distinguished (Table 1). Three groups contain only dry circulation types: AAD, ACD and CdD. The five groups of wet types are: AAW, WACW, EACW, WCdW and ECdW. All types from the XX sector are classified to group XX. This group, together with EACW, has the lowest frequency $(\sim 1 \%)$ in the 1981-2010 period, but both are specified because of their specific air temperature and rainfall distribution. The frequency for most of the remaining groups exceeds $10 \%$ (Fig. 10). 
DJF

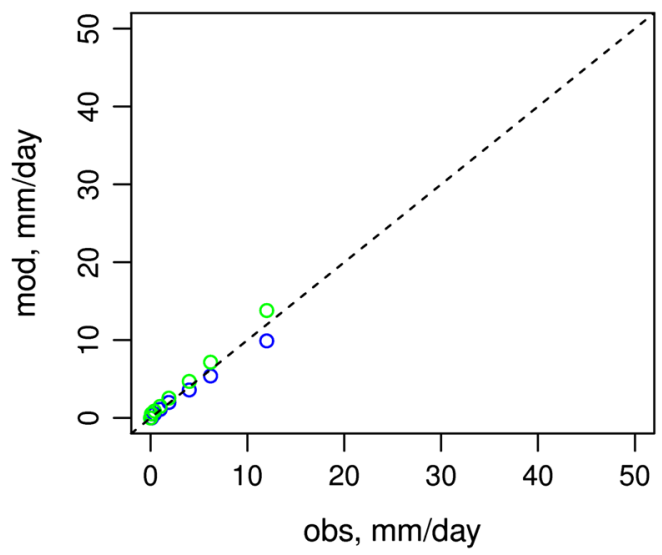

JJA

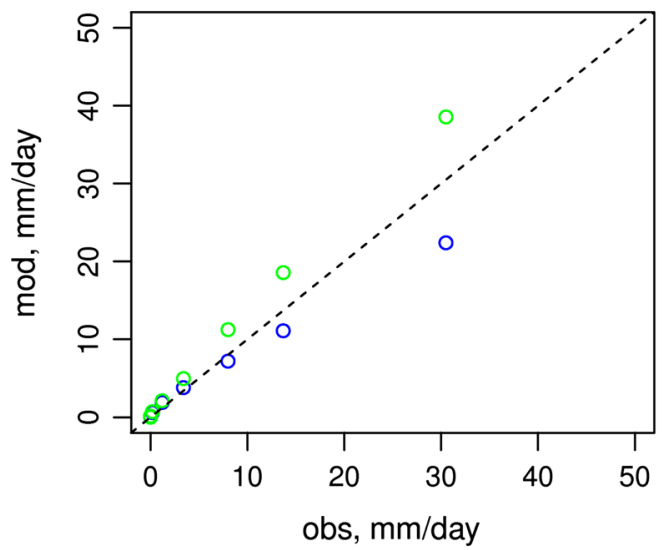

MAM

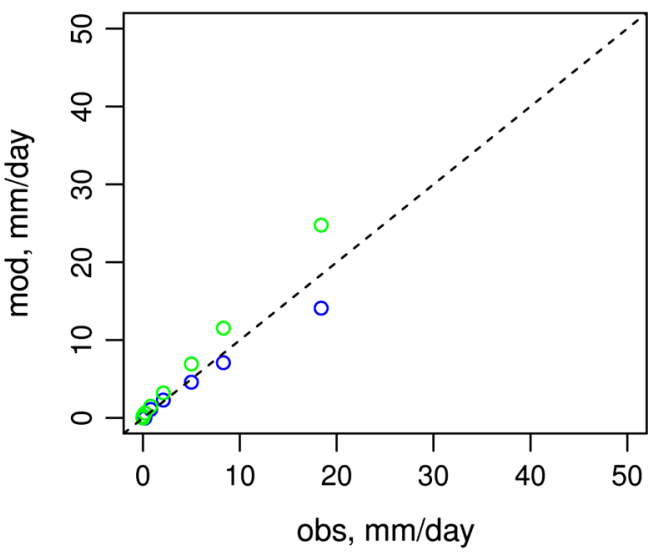

SON

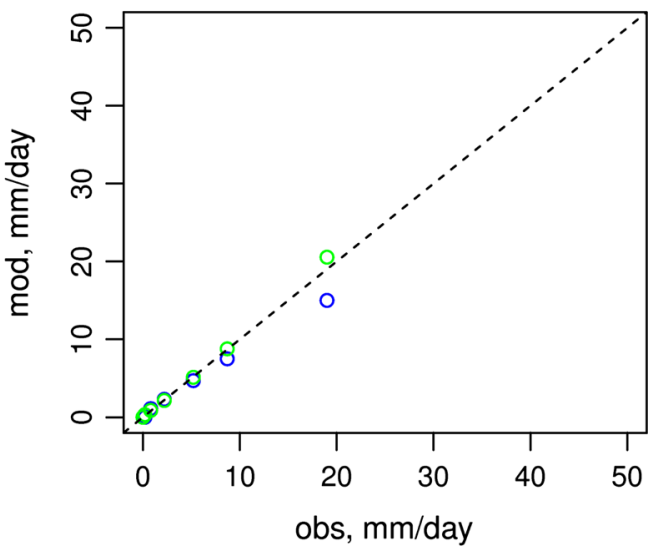

Figure 6

Quantiles $(0.025,0.1,0.25,0.5,0.6,0.7,0.8,0.9,0.95$ and 0.99$)$ for daily rainfall at $2 \mathrm{~m}$ for E-OBS (blue) and WRF (green). Mod is for modelled (WRF and E-OBS, $y$ axis) and obs is for observed values ( $x$ axis)

The WRF and E-OBS agreement with the measurements for the air temperature and rainfall, with respect to the circulation types, is summarised in Fig. 11. For the air temperature, the WRF data have small positive $\mathrm{ME}$ for all groups, and the $\mathrm{ME}$ is below $0.5{ }^{\circ} \mathrm{C}$ for most of the circulation types analysed, except for ECdW. For the E-OBS data, small $\mathrm{ME}$ is found for WACW, XX, ECdW and EACW types, for which the frequency of the occurrence is relatively low. For more frequent groups of types, e.g. groups $\mathrm{ACD}$ and $\mathrm{AAD}$, the E-OBS data overestimate the air temperatures above $0.5^{\circ} \mathrm{C}$, and the ME is significantly higher, compared with WRF. For the wet groups of AAW and WCdW, the E-OBS is underestimated and has the largest
MAE, while the WRF model shows small overestimation. The IOA for both datasets are very high for all the circulation types, both for E-OBS and WRF. The WRF model results have slightly higher values of IOA, especially for the wet circulation types with advection from the western sector (e.g. WCdW).

The WRF model overestimates the measured rainfall for all circulation types. This is especially the case for eastern or unidentified direction of advection (e.g. ECdW, EACW and XX; Fig. 11). Especially for group XX, ME shows almost two times higher rainfall in the period 1981-2010 than the measured value. On the contrary, the E-OBS database shows significant underestimation for the $\mathrm{XX}$ group. The MAE and IOA also show worse performance of 

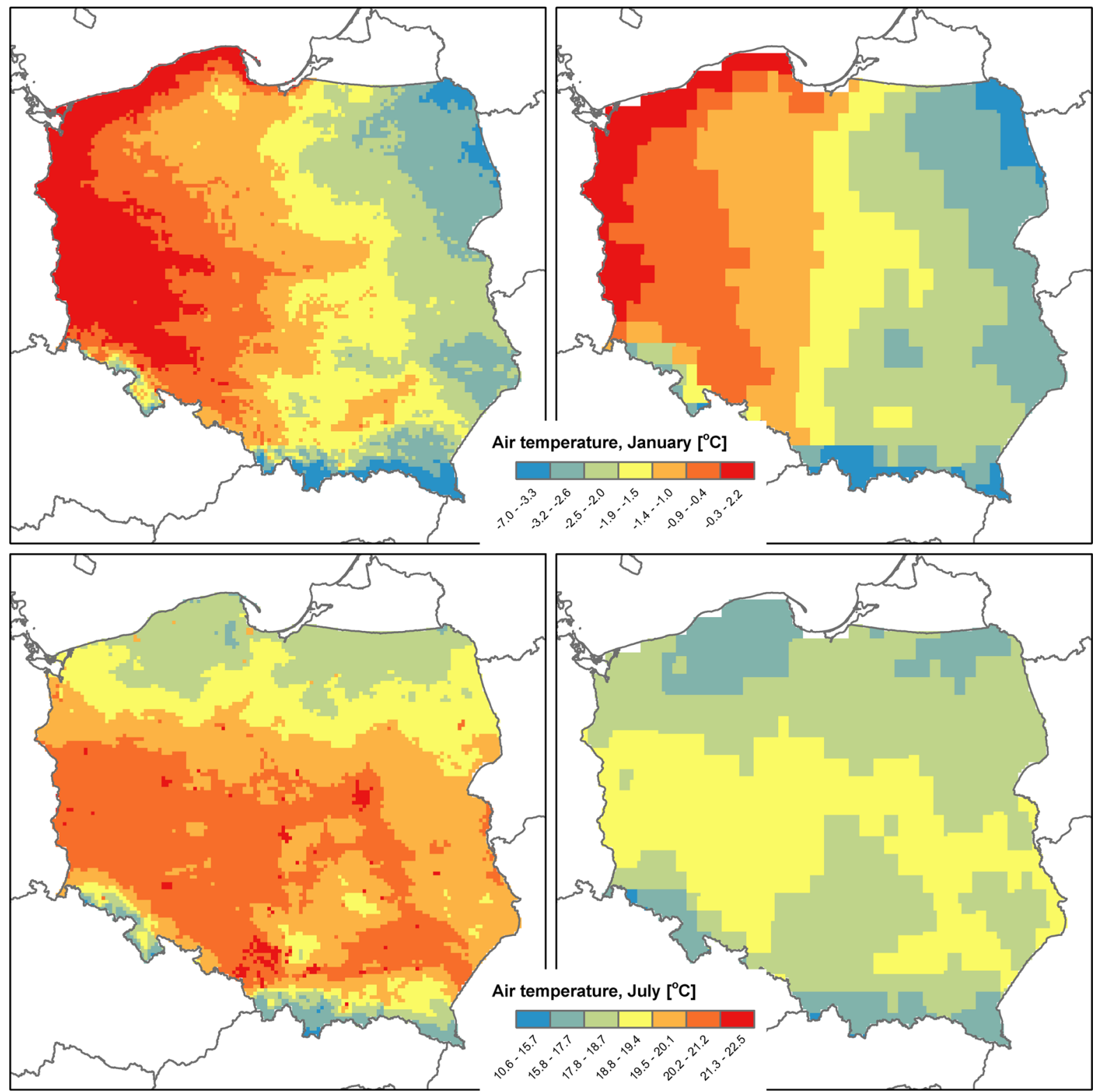

Figure 7

Spatial pattern of mean (1981-2010) air temperature for January (top row) and July (bottom) for WRF (left column) and E-OBS (right)

the WRF model for rainfall, compared to the E-OBS database, and MAE is especially large if the eastern wet types are considered (e.g. ECdW). For dry circulation types, MAE for the WRF model is below $1.5 \mathrm{~mm} /$ day, and for the majority of circulation types, the E-OBS MAE does not exceed $1.0 \mathrm{~mm} /$ day, except for the wet types of eastern advection. There were similar findings for the IOA statistics, which was higher for all the circulation types for E-OBS, compared to WRF. Both E-OBS and WRF show the lowest IOA for XX.

The statistical summary of the daily air temperature and rainfall is presented for the measurements, WRF and E-OBS data in Figs. 12 and 13. The variability of the air temperature and rainfall within each of the circulation type group is relatively small 

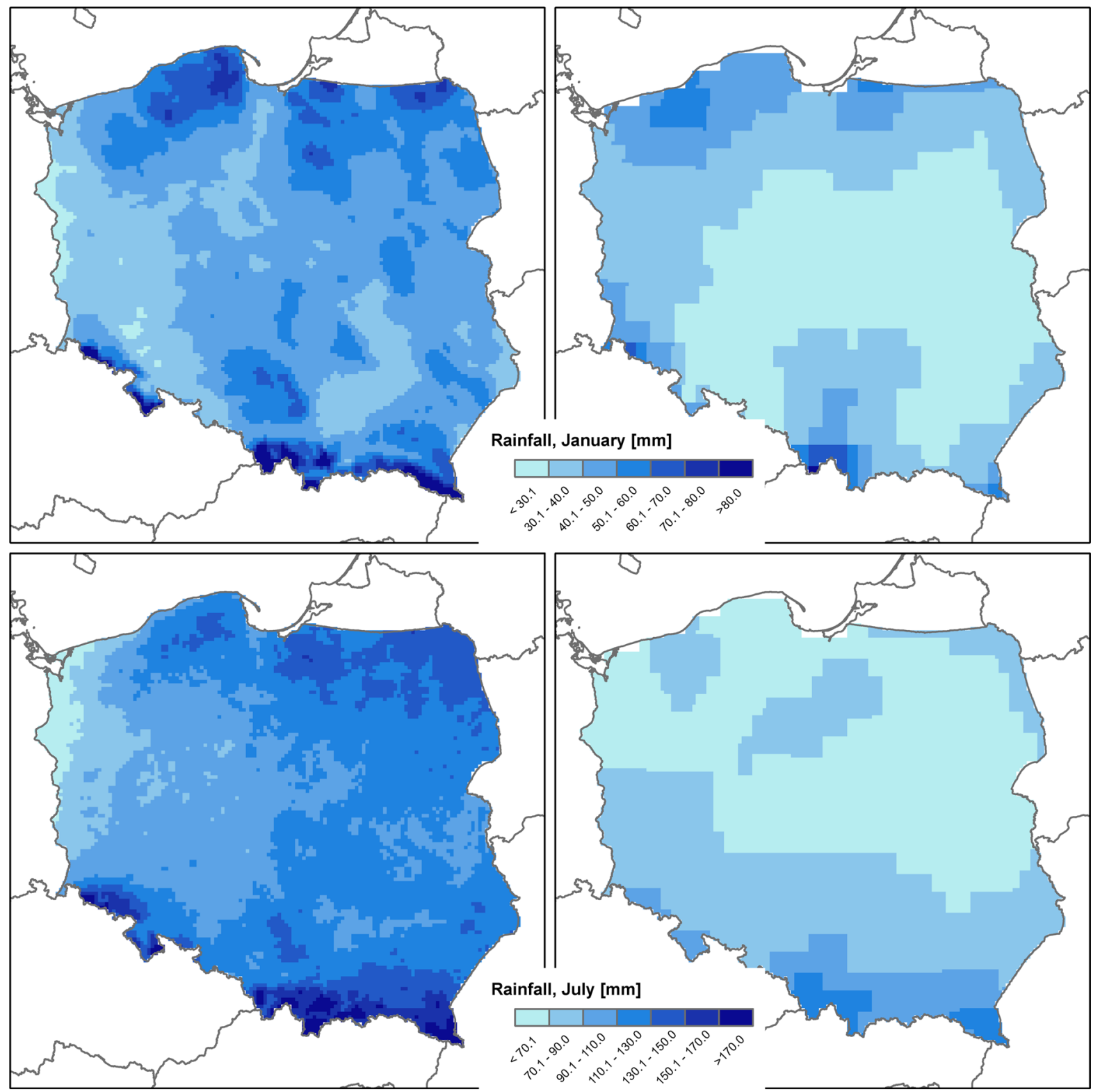

Figure 8

Spatial pattern of mean (1981-2010) monthly rainfall for January (top row) and July (bottom) for WRF (left column) and E-OBS (right)

and the groups are different in terms of, e.g. the median value. This suggests that the classification method properly distinguishes the circulation types, according to, e.g. KAlKstein et al. (1987) and Ustrnul et al. (2010). The largest differences in the median value between the circulation types and air temperature are observed in spring and reach $8{ }^{\circ} \mathrm{C}$ in $\mathrm{CdD}$ and EACW. The interquartile range is also the largest for spring, for which it reaches $8{ }^{\circ} \mathrm{C}$. The smallest differences in the median value between the groups of circulation types (about $1{ }^{\circ} \mathrm{C}$ ) concern dry type groups in the winter seasons (AAD, ACD, CdD) and wet, lower cyclonic groups in autumn (WCdW, ECdW). For all the seasons, the largest spread of air temperatures is the lower anticyclonic group of circulation types: AAD, AAW and ACD, which are 


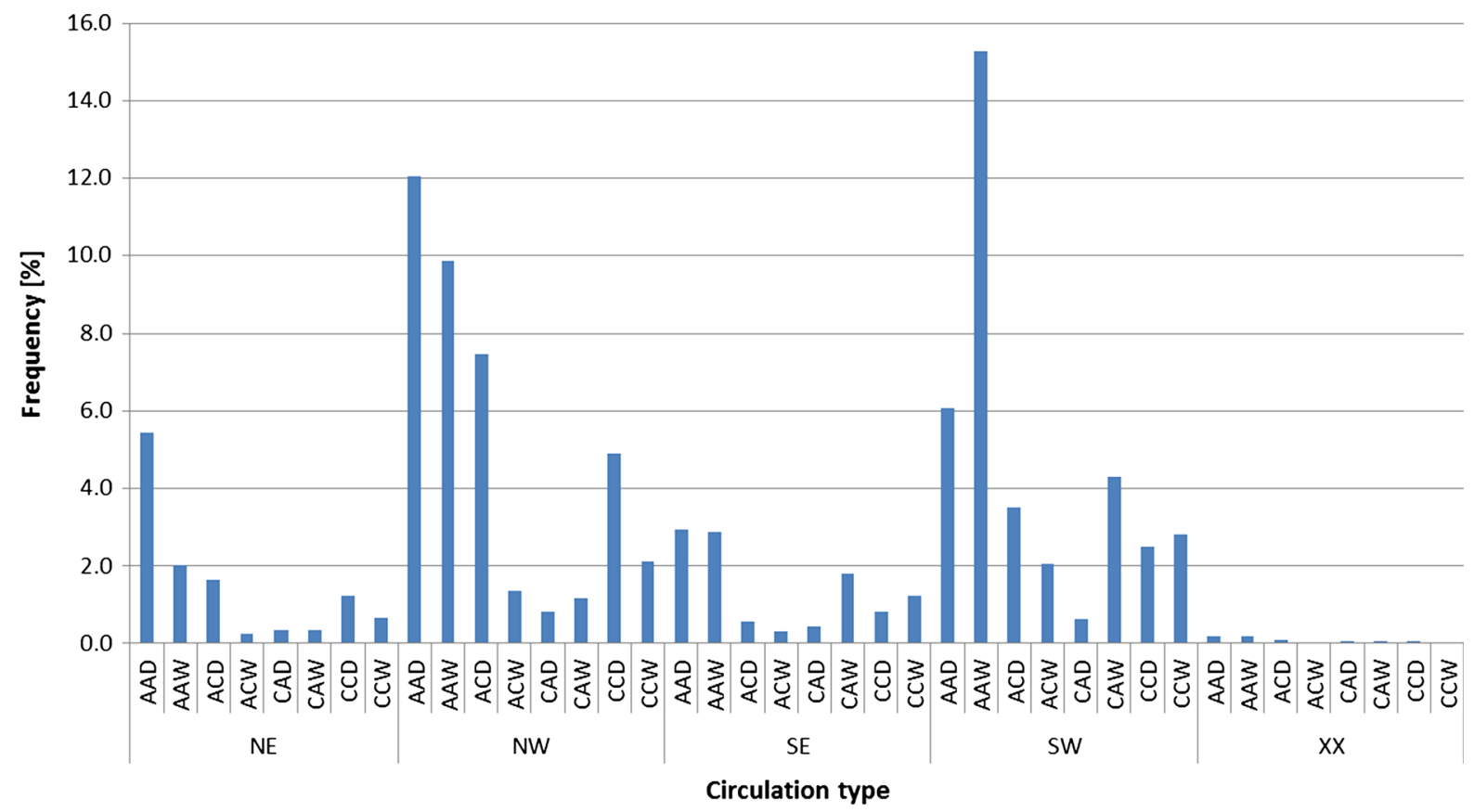

Figure 9

Frequency of circulation types for Poland in the years 1981-2010

Table 1

Circulation types and groups of circulation types determined using ACCT for the 1981-2010 period

Group of circulation types

Acronym Long name

AAD Lower anticyclonic, upper anticyclonic dry

ACD Lower anticyclonic, upper cyclonic dry

CdD Lower cyclonic dry

AAW Lower anticyclonic, upper anticyclonic wet

WACW Western, lower anticyclonic, upper cyclonic wet

EACW Eastern, lower anticyclonic, upper cyclonic wet

WCdW Western, lower cyclonic wet

ECdW Eastern, lower cyclonic wet

XX Unidentified direction of advection/without advection
Circulation types belong to the group

SWAAD, NWAAD, NEAAD, SEAAD

SWACD, NWACD, NEACD, SEACD

SWCCD, NWCCD, NECCD, SECCD, SWCAD, NWCAD, NECAD,

SECAD

SWAAW, NWAAW, NEAAW, SEAAW

SWACW, NWACW

NEACW, SEACW

SWCCW, NWCCW, SWCAW, NWCAW

NECCW, SECCW, NECAW, SECAW

XXAAD, XXAAW, XXACD, XXACW, XXCAD, XXCAW, XXCCD, $\mathrm{XXCCW}$ also the most frequent. For spring to autumn, an increased dispersion is found in the types with advection from the eastern sector (EACW, ECdW). The higher dispersion of the air temperatures for summer types with eastern advection could be related with the large variability of cloudiness and humidity in convective unstable air masses. The high extremes of temperature in $\mathrm{XX}$ and anticyclonic groups may be linked with long-lasting occurrence of this types and intense insolation and irradiation.

For precipitation, the differences between groups of circulation types are the highest for summer and winter (differences exceed $2 \mathrm{~mm} /$ day for the median value). The dispersion of precipitation values, according to the interquartile range, is the highest for the wet-type group, especially for AAW, WACW and 


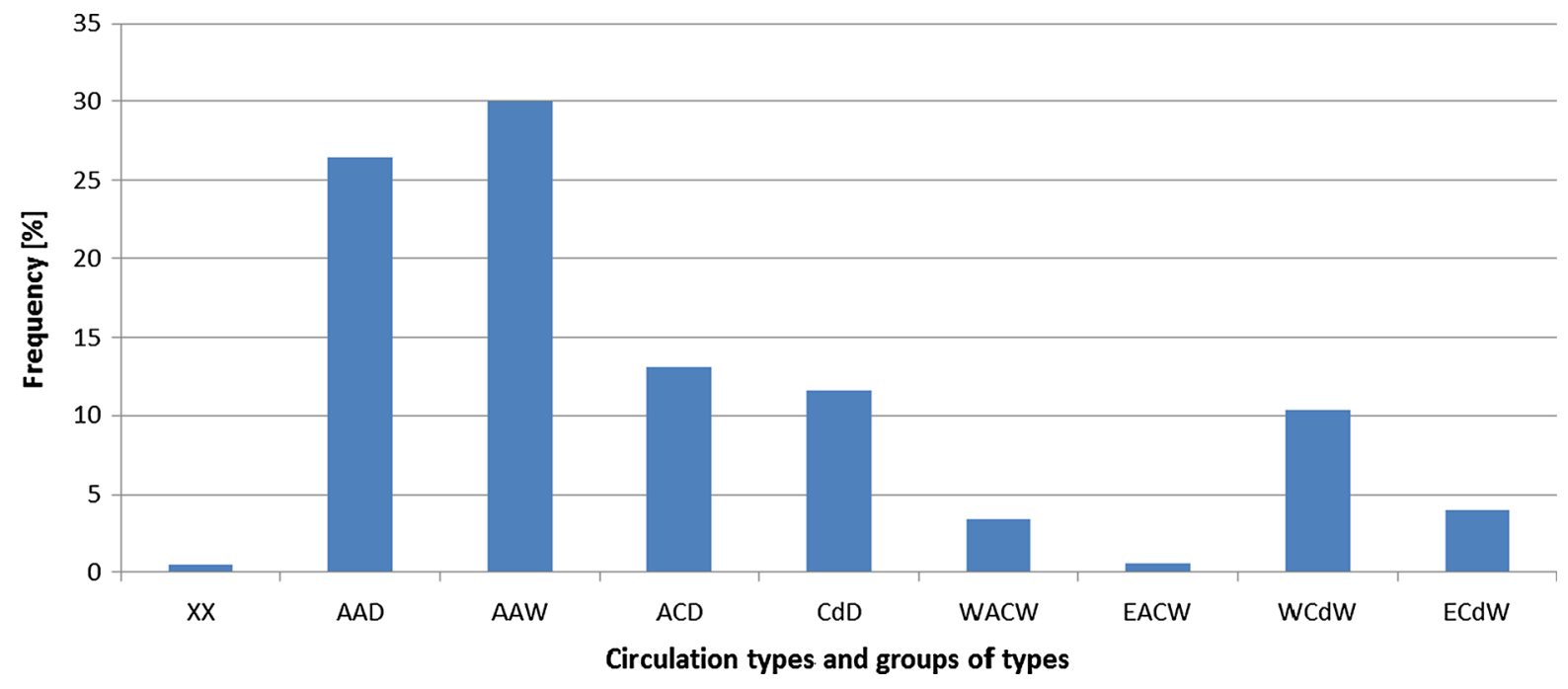

Figure 10

Frequency of groups of circulation types for Poland in the years 1981-2010

WCdW. Days with advection from the east (ECdW, $\mathrm{EACW}$ ) have a large interquartile range, except for the winter months. The outliers here reach $100 \mathrm{~mm} /$ day. There is a strong seasonal variability in the interquartile range for all groups of atmospheric circulation types. The values vary from 1.4 to $3.6 \mathrm{~mm} /$ day for winter months, to $3.2-7.2 \mathrm{~mm} /$ day for autumn. In summer, the interquartile range for most of the circulation-type groups is in the range from 5.2 to $7.0 \mathrm{~mm} /$ day and reaches the maximum $(14 \mathrm{~mm} /$ day) for group ECdW, which contains the types with unstable convective air masses.

The box plots presented in Figs. 12 and 13 also show the differences in the WRF and E-OBS data and the observations. This is especially true for the outliers, which were covered in the general model performance statistics presented above. For the air temperature and the winter months, there is a close agreement between the E-OBS and the measurements for the group types with high frequency (AAD, AAW , ACD , CdD) in terms of quartiles and the high outliers (Fig. 12). For groups $\mathrm{ACD}$ and $\mathrm{CdC}$, the WRF model also shows a very good agreement with the measurements, but for the lower and upper anticyclonic group types (AAD, AAW) and most of the less frequent groups of circulation types, the median temperature together with the first and third quartile is lower, compared with the measurements.
The WRF model, in general, better reproduces the lower outliers when compared with E-OBS, and for the majority of the groups in winter, the lower outliers are underestimated by WRF and overestimated by E-OBS. For the less frequent type of group, excluding XX, the WRF model shows closer agreement with the measured air temperatures than the E-OBS..

For spring and summer, both E-OBS and the WRF models reproduce the air temperatures well, especially for the wet type (Fig. 12). For summer, the WRF model overestimates the median value for the majority of the circulation types. The differences between the temperature quartiles from WRF and observed datasets are small and usually do not exceed $1{ }^{\circ} \mathrm{C}$. For groups AAW and WCdW, the WRF model shows higher maximum values of air temperatures, compared with the measurements, for both spring and summer. In summer, WRF shows closer agreement with the measurements for the low outliers, but, similar to E-OBS, the model overestimates air temperature. In spring, the WRF model reproduces well the higher air temperatures.

For autumn, the WRF model reproduces well the median value both for frequent and rare circulation types. The high values are usually overestimated, especially for the most common circulation types of AAD, AAW and ACD, for which the E-OBS shows a 

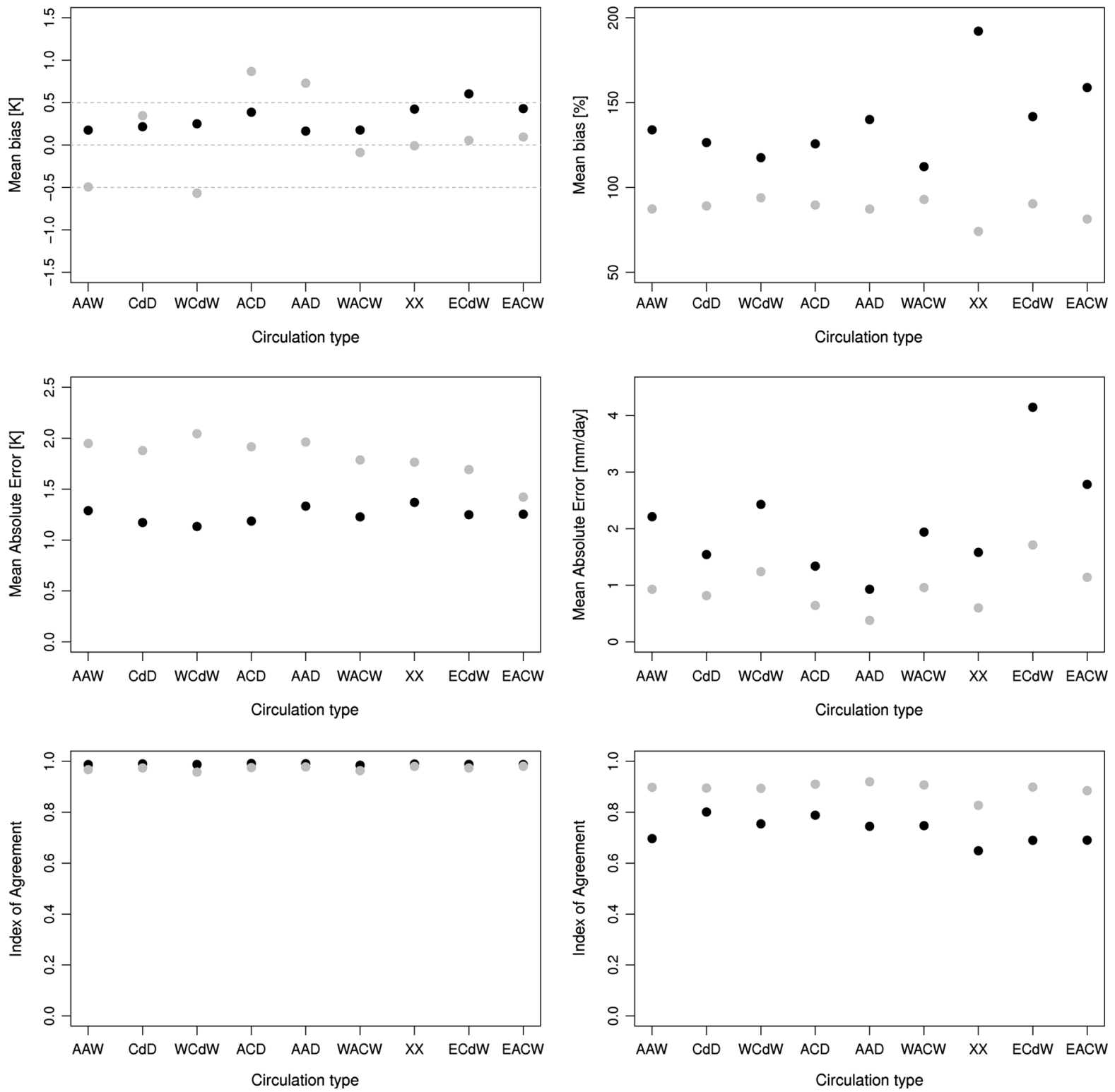

Figure 11

Statistical performance of WRF (black points) and E-OBS (grey points) for daily air temperature (left column) and rainfall above $0.1 \mathrm{~mm} / \mathrm{day}$ (right column) according to the group of circulation types

closer agreement with the measurements than WRF. However, for the less frequent groups, like WCdW or EACW, the upper outliers are better represented by the WRF model.

For rainfall, the box plots show that for the WRF model there is a significantly higher number of days with rainfall, compared to the measurements (Fig. 13). On the contrary, the E-OBS data give a
Figure 12

Comparison of the observed (red) and WRF (green) and E-OBS (blue) modelled air temperature for the 1981-2010 period for circulation types. Box plot width is proportional to the group of circulation-type frequency. The box plot hinges show the first and third quartiles, the whiskers are 1.5 times the hinges spread or to the data extreme (if $1.5^{*}$ the hinge spread is smaller than the extreme value) and circles are the outliers, which are above/below the 1.5 times the box length 

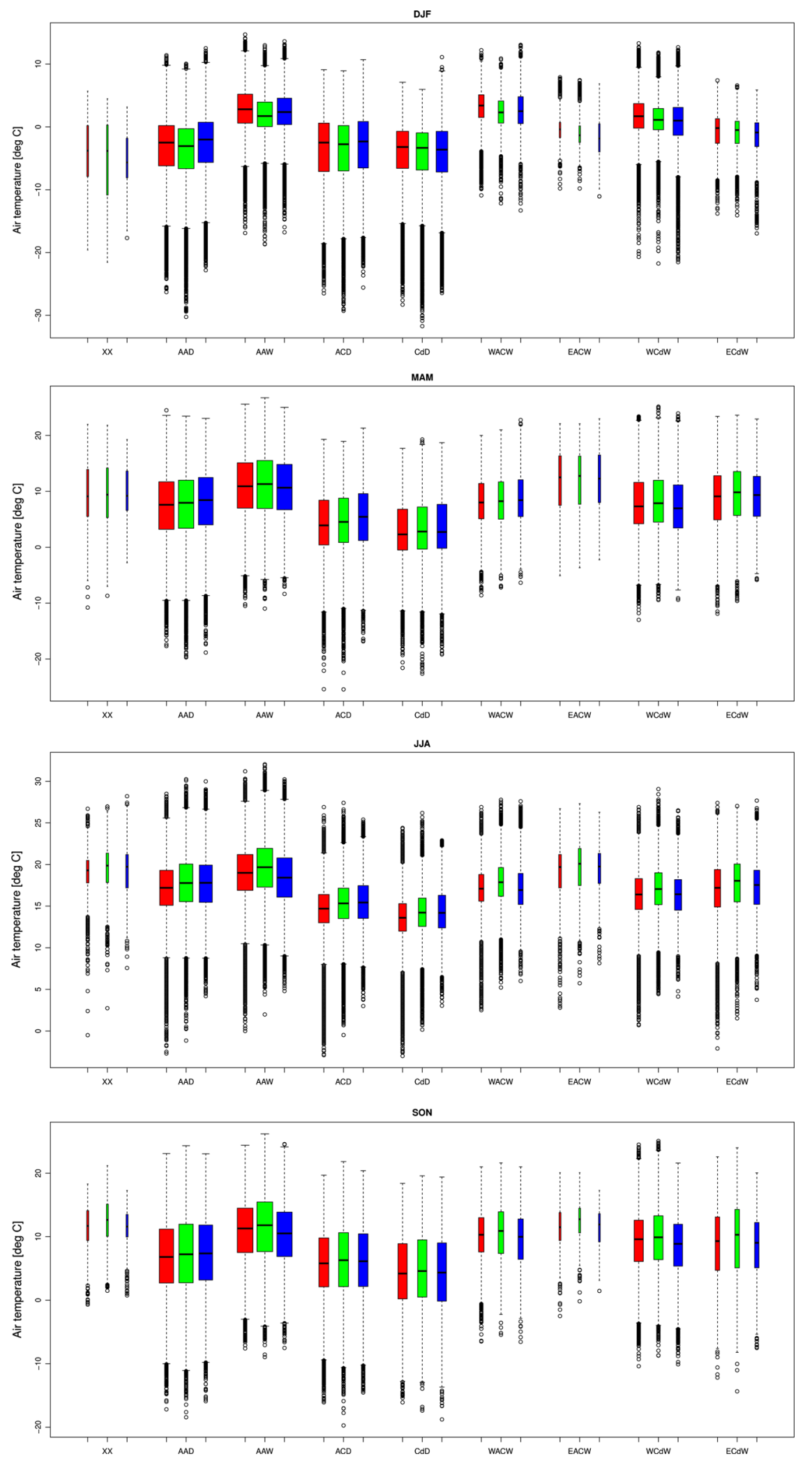
smaller number of days with rainfall compared to the measurements. Regardless of the season, the median values of precipitation for WRF data are in a better agreement with the measurements than E-OBS for the majority of the circulation types, especially in groups AAW, WCdW and ACD. For summer, the WRF model gives higher daily rainfall for all the circulation types. The same is observed for winter and spring in the lower cyclonic types of the group. For autumn, the WRF median is higher, compared to the measurements only for AAW and ECdW.

For the majority of the circulation types and regardless of the season, the first quartile for the WRF model is about $0.1 \mathrm{~mm}$ higher, compared with the observations, while this difference for E-OBS exceeds $1.0 \mathrm{~mm}$, especially for the spring and summer months (Fig. 13). For higher daily rainfall values, represented by the third quartile, the E-OBS is in better agreement with the measurements for all circulation types, except for the autumn and winter months. For all the circulation types, the third quartiles of precipitation in the WRF model are 0.5-2.0 mm higher than in the observed datasets in spring and summer. In the winter and autumn months, they are about $1.0 \mathrm{~mm}$ lower, but only for lower anticyclonic groups of circulation types, with any differences in other groups. The WRF model also shows higher than measured highest daily rainfall values for all the circulation types, but these extreme values are in closer agreement with the observation than for E-OBS.

For a spatial evaluation of the WRF model results for the daily mean air temperature and rainfall, with respect to the circulation type, we used the E-OBS data. The most important result is that the differences between the WRF and E-OBS are not spatially constant and change with the circulation type. The example is presented in Fig. 14 for the air temperature, with the most common lower/upper anticyclonic wet circulation type (AAW) and eastern, lower anticyclonic, upper cyclonic wet type (EACW). For the AAW circulation type, the highest IOA is for northern and eastern Poland. For EACW, the highest values are for northern and western areas of the country. For EACW, there is a large area of decreased IOA in SE Poland, which is not visible for AAW. The absolute minimum values are different
Figure 13

Comparison of the observed (red) and WRF (green) and E-OBS (blue) modelled daily rainfall (above $0.1 \mathrm{~mm} /$ day) for the 1981-2010 period for circulation types. Box plot width is proportional to the number of days with rainfall for a given circulation type. Please notice the $\log Y$ axis. The box plot hinges show the first and third quartiles, the whiskers are 1.5 times the hinges spread or to the data extreme (if $1.5^{*}$ the hinge spread is smaller than the extreme value) and circles are the outliers, which are above/below 1.5 times the box length

for AAW and EACW, but cover approximately the same area of southern Poland. Similarly, there are large changes in spatial distribution of ME for these circulation types. The lowest ME covers the northern and eastern areas of Poland for AAW, while for EACW it is N and NW. The largest values are for central and southern Poland in AAW, while for EACW there is a large area of high ME in SE Poland. The same changes in the WRF and E-OBS spatial agreement are found for rainfall (Fig. 15). There are also large changes, e.g. in IOA which is significantly lower for AAW compared to EACW.

\section{Summary and Conclusions}

In our study, we have presented the results of high-resolution dynamical downscaling of daily rainfall and air temperature with the regional climate model WRF. The results were evaluated by comparison with measurements and gridded data. Additionally, we presented the method for automatic classification of atmospheric circulation types, which utilize the high-resolution WRF model output. The method for the automatic classification of the circulation types (ACCT) for Poland, based on the WRF data (wind direction, cyclonality and humidity of air masses), was applied for the entire period of 1981-2010. The WRF model performance was evaluated for daily precipitation and air temperature, individually for each month and also with respect to the group of circulation types. The analysis of the regional dynamical downscaling with the WRF model was complemented by comparison with spatial data obtained with the geostatistical method (EOBS).

The main findings of this work are: 

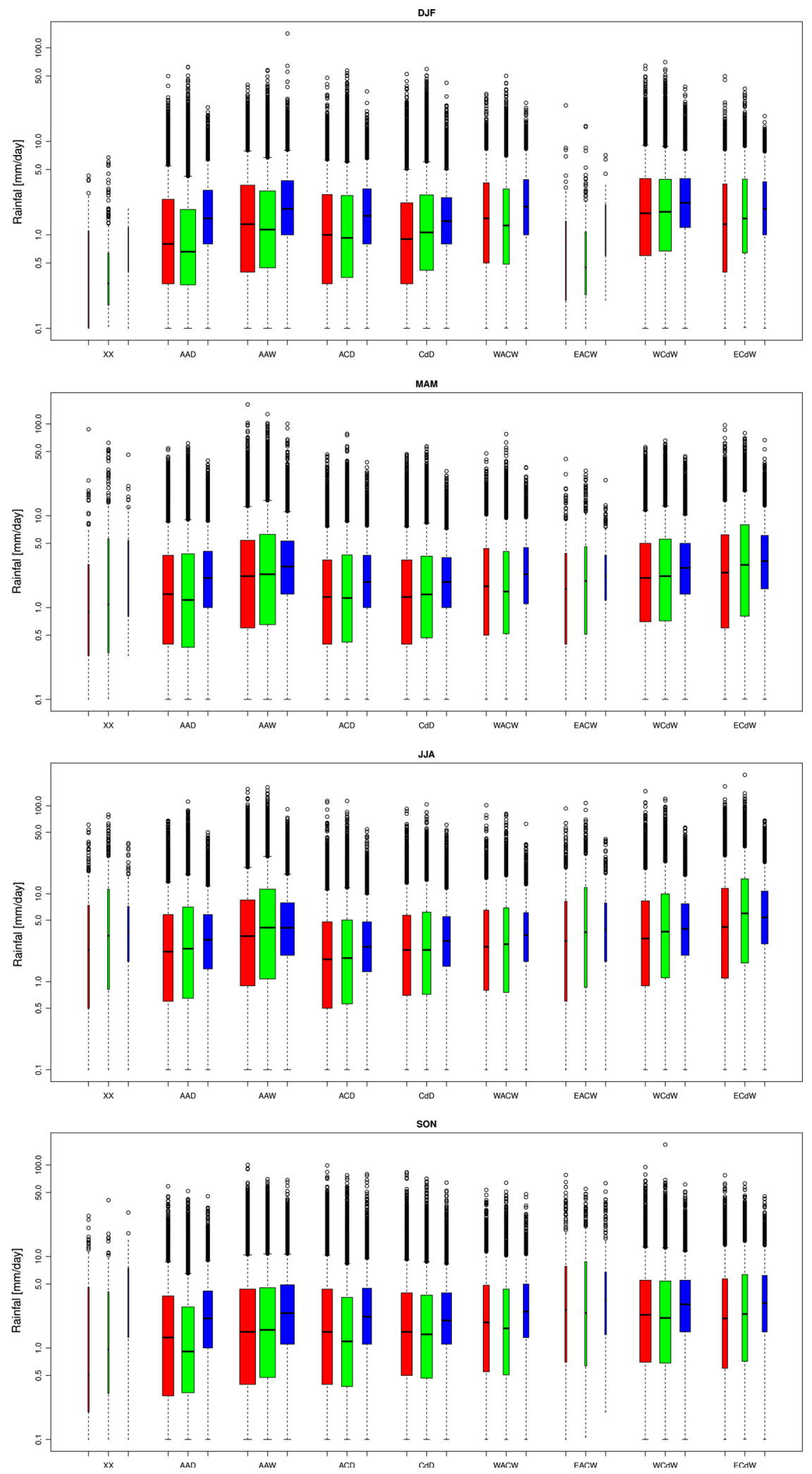


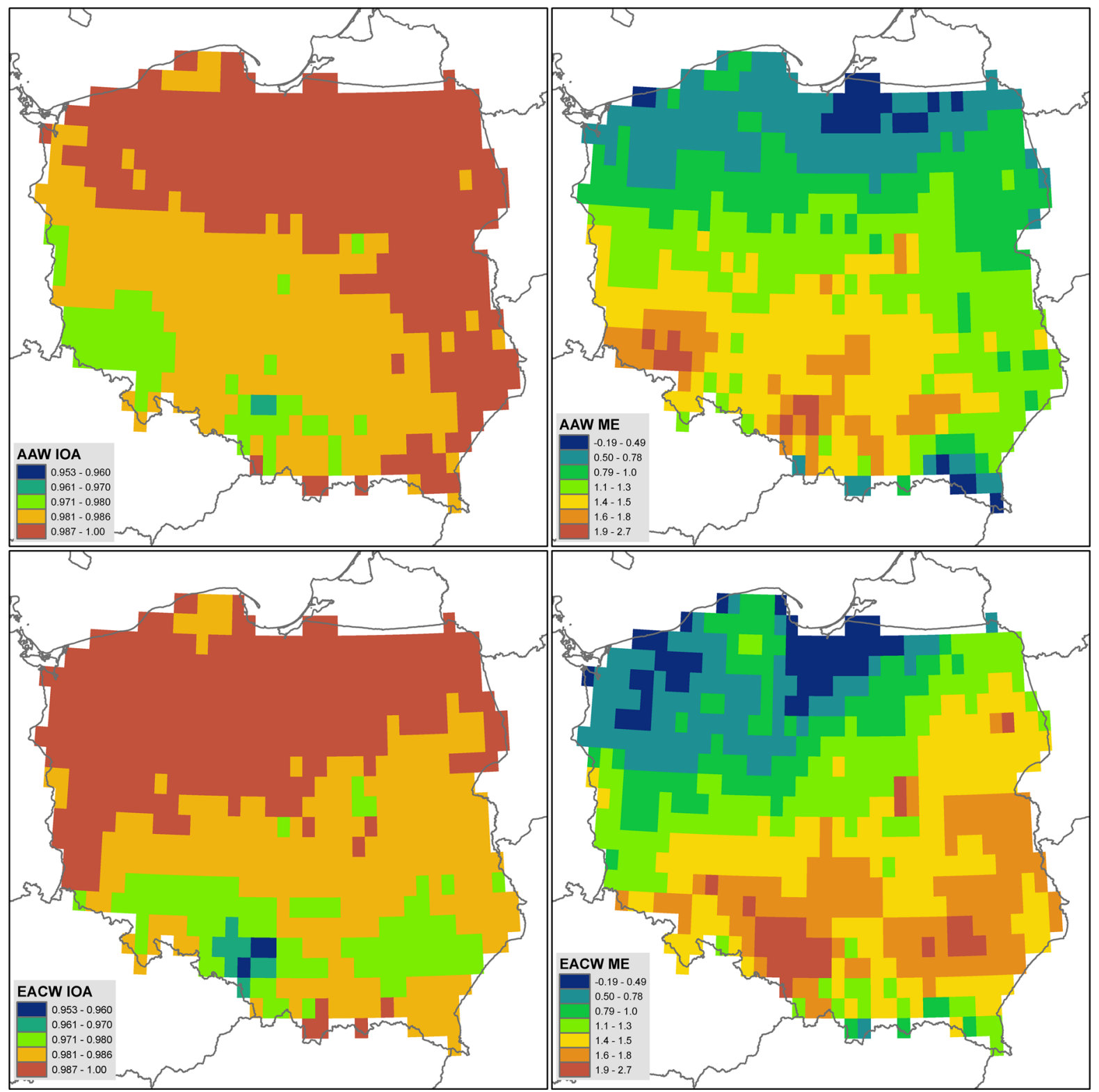

Figure 14

ME and IOA between the WRF and E-OBS air temperature data for AAW and EACW circulation types in the 1981-2010 period

- A tool for automatic derivation of circulation schemes was developed and used with highresolution gridded meteorological data. The tool is flexible in terms of spatial domain resolution, location and meteorological input. The advantage of ACCT classification is that it provides the opportunity of type grouping depending on the research aim, while in long time series, a large number of circulation types permit detailed case studies. The classification scheme can also be extended by incorporating other classification criteria.

- The variability of the air temperature and precipitation between particular types and groups of circulation types confirmed the usefulness of the classification methodology. The worst results were connected with the anticyclonic group type and with the types with unstable convective air masses. 


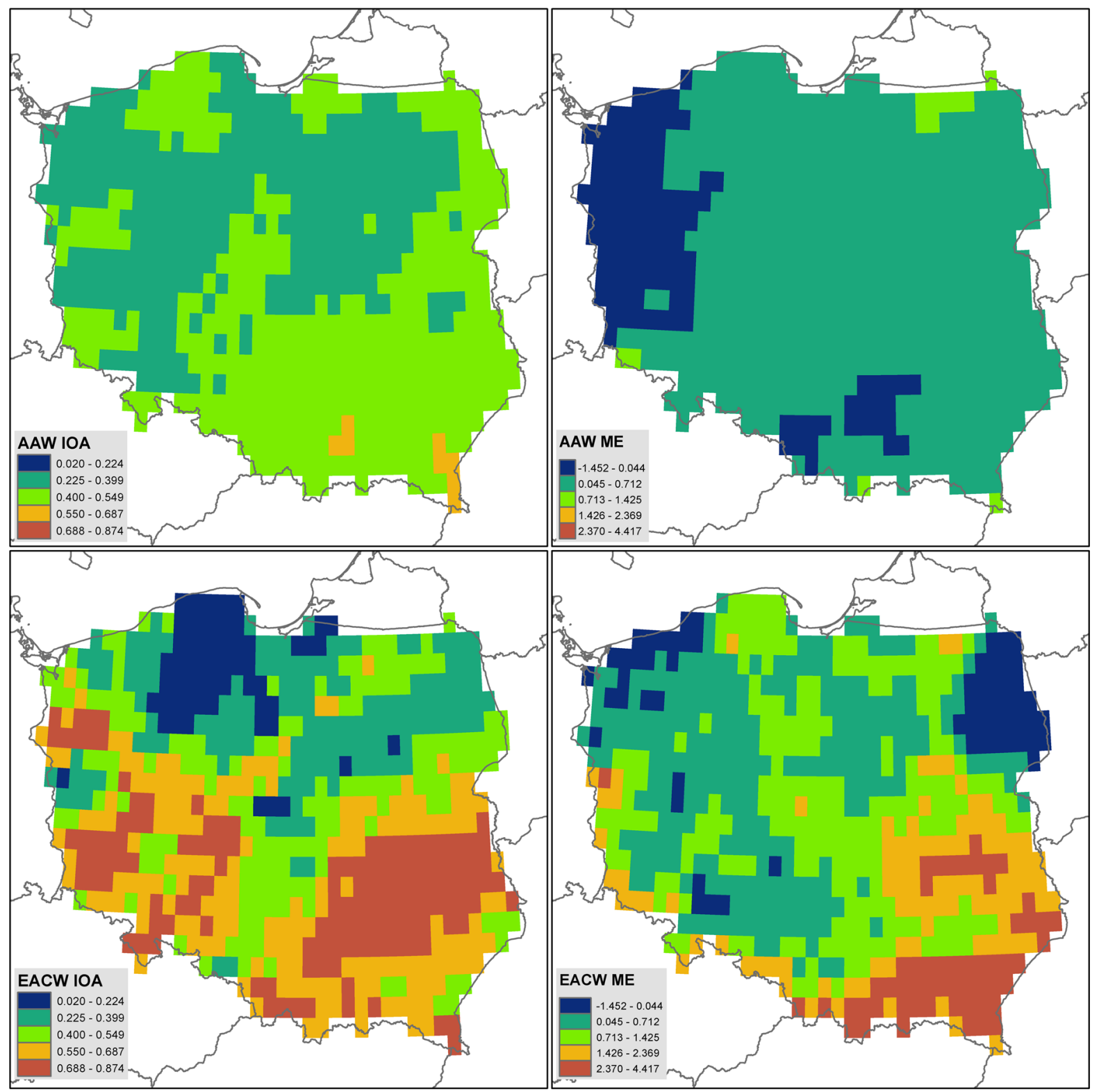

Figure 15

ME and IOA between the WRF and E-OBS rainfall data for AAW and EACW circulation types in the 1981-2010 period

The authors are aware that worse results, in terms of larger variability of meteorological parameters, could be caused by the difficulty in choosing the mode value of classification types for the large area of Poland, with its considerable spatial variability. The classification scheme will therefore be modified to allow for spatial variability of circulation type for a given day within the area that is analysed.
- In general, the WRF model shows a good agreement with the observed daily air temperature, especially for its lowest values. The higher air temperatures are, except for the winter months, overestimated. The error statistics of ME, MAE and IOA for WRF also show a better model-measurements agreement compared to E-OBS. The E-OBS overestimates the lower air temperatures in most seasons, which might be linked with the coarser spatial resolution 
compared to WRF. The spatial patterns of the air temperature and rainfall are similar for both WRF and E-OBS, when the long-term mean values are compared. The WRF model shows a larger spatial variability because of the higher spatial resolution.

- The close WRF-measurements agreement, quantified by ME, MAE and IOA for the air temperatures, is independent of group of circulation types. However, there is a seasonal variability in temperature agreement in particular circulation types considered. In contrast to small overestimation for all circulation types for spring and autumn, the winter months are underestimated, especially for frequent lower and upper anticyclonic groups of types (AAW, AAD). For all the seasons, except the summer, the WRF model shows lower, compared with the measurements, minima of the air temperature. In winter, the WRF model better reproduces the air temperatures for the coldest groups of circulation types ( $\mathrm{ACD}, \mathrm{CdD}$ ). For warmer groups of circulation types in winter and autumn, E-OBS is in better agreement with the measurements. In spring and summer months, the mean air temperatures are in closer agreement with the measurements for the WRF model.

- The error statistics for the rainfall shows a worse performance of the WRF model, compared with E-OBS. This is especially the case for the summer months. The WRF model overestimates the measured rainfall, especially the higher daily values. The WRF model also gives more days with rainfall, compared to the measurements. However, the E-OBS underestimates the precipitation values mainly in the summer and autumn months.

- The differences between WRF and E-OBS for precipitation are similar in all groups of circulation types. For the spring and summer months, the WRF model overestimates the daily precipitation sums. This overestimation is especially large for the $\mathrm{XX}$ and eastern groups of circulation types. The maximum sums of precipitation for WRF are higher than the observed values, but are in better agreement with the measurements when compared to E-OBS. In winter and autumn, the modelled precipitation sums are close to the measurements (e.g. in $\mathrm{WCdW}$ ) or underestimated for the lower anticyclonic-type groups.
- The spatial distribution of the differences between the WRF and E-OBS data changes significantly according to the atmospheric circulation type. This is of significant practical importance, as the largescale atmospheric circulation pattern determines the uncertainty related to the meteorological information provided by the WRF model.

In this work we have shown that the WRF model performance depends strongly on the type of atmospheric circulation. This is especially the case for rainfall. This suggests that the model evaluation should also consider some indices related with circulation types, as presented in this study. Also, it means that the circulation type can be used to assess the uncertainty related with the numerical weather forecasting. High-resolution WRF model data can be used to determine the circulation types using the ACCT, with respect to, e.g. humidity of air mass.

The overall poor WRF model performance for rainfall shows the need for improvement. The uncertainty in the WRF model prediction for rainfall is high and changes both seasonally and with circulation type. The model performance could be improved, e.g. by data assimilation (e.g. GNSS data, as suggested by Schwitalla et al. 2011).

\section{Acknowledgments}

This work was supported by the National Science Centre (NCN), Poland (Grants Nos. NN404 014740 and UMO-2011/03/B/ST10/06226). Calculations have been carried out in the Wroclaw Centre for Networking and Supercomputing (http://www.wcss. wroc.pl), Grant No. 170. Meteorological measurements for this work were provided by the Institute of Meteorology and Water Management, National Research Institute.

Open Access This article is distributed under the terms of the Creative Commons Attribution 4.0 International License (http:// creativecommons.org/licenses/by/4.0/), which permits unrestricted use, distribution, and reproduction in any medium, provided you give appropriate credit to the original author(s) and the source, provide a link to the Creative Commons license, and indicate if changes were made. 


\section{REFERENCES}

Badger, J., Frank, H., Hahmann, A.N., Giebel, G. (2014), Windclimate estimation based on mesoscale and microscale modelling: statistical-dynamical downscaling for wind energy applications, Journal of Applied Meteorology and Climatology 53, 1901-1919.

BEDNORZ, E. (2012), Atmospheric conditions of intense thaws in the Polish lowlands, Meteorologische Zeitschrift, Vol. 21, No. 1, 89-98, doi:10.1127/0941-2948/2012/0228.

Bednorz, E., Wibig, J. (2008), Snow depth in eastern Europe in relation to circulation patterns, Annals of Glaciology 48, 135-149, doi:10.3189/172756408784700815.

Bielec-BäKowsKa, Z., ŁuPIKASZA, E. (2009), Frosty, freezing and severe freezing days and their synoptic implications in Matopolska, Southern Poland, 1951-2000, Bulletin of Geography—physical geography series, No. 1, 39-62.

Bissolli, P., DitTmann, E. (2001), The objective type classification of the German Weather Service and its possibilities of application to environmental and meteorological investigations, Meteorologische Zeitschrift, Vol. 10, No. 4, 253-260.

CZERNECKI, B. (2013), Creating wind field time-series over the Southern Baltic area using a dynamical downscaling approach, Meteorologische Zeitschrift Vol. 22, 587-593.

Emery, C., TAI, E., Greg, Y. (2001) Enhanced Meteorological Modeling and Performance Evaluation for Two Texas Ozone Episodes. Report to the Texas Natural Resource Conservation Commission, College Station, TX, USA, pp 235

Fuentes U, Heimann D (2000): An improved statistical-dynamical downscaling scheme and its application to the Alpine precipitation climatology. Theor. Appl. Climatol. 65: 119-135.

Gerstengarbe, F.W., Werner, P.C., Busold, W., Rüge, U., Wegener, K.O., Katalog der Grosswetterlagen Europas nach Paul Hess und Helmut Brezowsky 1881-1992 (Deustcher Wetterdienst, Offenbach am Main 1993).

GiORGI, F., BATES, T. (1989) The climatological skill of a regional model over complex terrain, Monthly Weather Review 117, 2325-2347.

Haylock, M.R., Hofsta, N., Klein Tank, A.M.G., Klok, E.J., JoNES, P.D., NEw, M. (2008), A European daily high-resolution gridded data set of surface temperature and precipitation for 1950-2006, Journal of Geophysical Research 113, doi:10.1029/ 2008JD010201.

Huth, R., Beck, C., Philipp, A, Demuzere, M., Ustrnul, Z., Cahynova, M., Kysely, J., Tveito, O.E. (2008), Classifications of Atmospheric Circulation Patterns Recent Advances and Applications, Trends and Directions in Climate Research 1146, $105-152$.

JEZIORSKA, J., NiedZIELSKI, T. (2015), Applicability of TOPMODEL in the mountainous catchments in the upper Nysa Ktodzka River basin (SW Poland), Pure and Applied Geophysics (this issue).

Jiménez, P.A., Dudhia, J., González-Rouco, J.F., Montávez, J.P., García-Bustamante, E., Navarro, J., Vilà-Guerau de ArelLANo, J., MuÑoz-Roldán, A. (2013), An evaluation of WRF's ability to reproduce the surface wind over complex terrain based on typical circulation patterns, Journal of Geophysical Research: Atmospheres 118, 7651-7669.

Kalkstein, L.S., Tan, G., Skindlov, J.A. (1987), An evaluation of three clustering procedures for use in synoptic climatological classification, Jour. Appl. Meteor., 26, 17-730.
Kryza, M., Wałaszek, K., Ojrzyńska, H., Szymanowski, M., Werner, M., Dore, A.J. (2016), High-Resolution Dynamical Downscaling of ERA-Interim Using the WRF Regional Climate Model for the Area of Poland. Part 1: Model Configuration and Statistical Evaluation for the 1981-2010 Period, Pure and Applied Geophysics, doi:10.1007/s00024-016-1272-5

Kożuchowski, K., Wibig, J., Maheras, P. (1992), Connections between air-temperature and precipitation and the geopotential height of the 500-hpa-level in a meridional cross-section in Europe, International Journal of Climatology 12, 343-352.

LityŃski, J. (1969), Liczbowa klasyfikacja typów cyrkulacji i typów pogody dla Polski, Prace PIHM, 97, 3-14.

Lo, J.C.F., YAng, Z.L., Pielke, R.A. (2008), Assessment of three dynamical climate downscaling methods using the Weather Research and Forecasting (WRF) model, Journal of Geophysical Research-Atmospheres 113.

ŁUPIKASZA, E. (2010), Relationships between occurrence of high precipitation and atmospheric circulation in Poland using different classifications of circulation types, Physics and Chemistry of the Earth, 35(9), 448-455, doi:10.1016/j.pce.2009.11.012.

Mendez, M., Garcia-Diez, M., Fita, L., Fernandez, J., Mendez, F.J., GutierreZ, J.M. (2014), High-resolution sea wind hindcasts over the Mediterranean area, Climate Dynamics 42, 1857-1872.

NIEDźwIEDź, T., Sytuacje synoptyczne i ich wpływ na zróżnicowanie przestrzenne wybranych elementów klimatu w dorzeczu górnej Wisły (Rozpr. Hab. UJ 58, Kraków 1981).

OJRZYŃSKA, H., Circulation conditionings of air temperature spatial differentiation in morphologically diverse area with the use of an example of the Western Sudeten (pl. Cyrkulacyjne uwarunkowania przestrzennego rozkładu temperatury powietrza w terenie zróżnicowanym morfologicznie na przykładzie Sudetów), (Rozprawy Naukowe Instytutu Geografii i Rozwoju Regionalnego, 36, Wrocław 2015).

OsuchowsKa- KLEIN, B., Katalog typów cyrkulacji atmosferycznej (WKit, Warszawa 1978).

OsuchowsKa-KLeIN, B., Związek miedzy temperatura a cyrkulacją atmosferyczną (Mat. Bad. IMGW, ser. Meteorologia 17, Warszawa 1992).

Piotrowski, P., Obiektywna metoda klasyfikacji cyrkulacji atmosferycznej dla Polski, (Acta Universitatis Lodziensis, Folia Geographica Physica, 10, Wyd. UŁ, Łódź 2009).

Reyers M, Pinto JG, Moemken J (2015): Statistical-dynamical downscaling for wind energy potentials: evaluation and applications to decadal hindcasts and climate change projections. Int. J. Climatol. 35: 229-244.

Schwitalla, T., Bauer, H.-S., Wulfmeyer, V., Aoshima, F. (2011), High-resolution simulation over central Europe: assimilation experiments during COPS IOP 9c, Quarterly Journal of the Royal Meteorological Society 137: 156-175. doi:10.1002/qj.721.

Skamarock, W.C., Klemp, J.B., Dudhia, J., Gill, D.O., Barker, D.M., Duda, M., Huang, X.-Y., Wang, W., Powers, J.G. (2008), A description of the advanced research WRF version 3, Technical report TN-475 + STR, NCAR.

Szymanowski, M., Kryza, M., Spallek, W. (2013), Regressionbased air temperature spatial prediction models: an example from Poland, Meteorologische Zeitschrift 22, 557-585.

The NCAR Command Language (Version 6.1.2) [Software]. (2013). Boulder, Colorado: UCAR/NCAR/CISL/VETS. doi:10. 5065/D6WD3XH5. 
Twardosz, R., Niedźwiedź, T. (2001), Influence of synoptic situations on the precipitation in Krakow (Poland), International Journal of Climatology, Vol. 21, 4, 467-481, doi:10.1002/joc. 620.

Twardosz, R., Niedźwiedź, T., Łupikasza, E. (2011), The influence of atmospheric circulation on the type of precipitation (Kraków, southern Poland), Theoretical and Applied Climatology, 104, 233-250, doi:10.1007/s00704-010-0340-5.

Ustrnul, Z., Zmienność cyrkulacji atmosfery na półkuli północnej w XX wieku (Mat. Bad. IMGW, ser. Meteorologia, 27, Warszawa 1997).

Ustrnul, Z. (2000), Synoptic - climatic structure of the extreme air thermal phenomena in Poland, Geographia Polonica 73(2), 99-109.

Ustrnul, Z. (2006), Spatial differentiation of air temperature in Poland using circulation types and GIS, Int. J. Climatol., Vol. 26, 1529-1546.

Ustrnul, Z., CZEKIERDA, D., WyPYCH, A. (2010), Extreme values of air temperature in Poland according to different atmospheric circulation classifications, Physics and Chemistry of the Earth, 35, 429-436.
Ustrnul, Z., Wypych, A., Winkler, J.A., Czekierda, D. (2014), Late spring freezes in Poland in relation to atmospheric circulation, Quaestiones Geographicae 33(3), 165-172.

WiBIG, J., Związki wybranych elementów klimatu Polski z cyrkulacjąna powierzchni izobarycznej $500 \mathrm{hPa}$ nad Europą i północnym Atlantykiem (Phd dissertation, Katedra Meteorologii i Klimatologii UŁ, Łódź 1991).

WIBIG, J., Wpływ cyrkulacji atmosferycznej na rozkład przestrzenny anomalii temperatury i opadów w Europie (Rozprawy habilitacyjne UŁ, Wyd. UŁ, Łódź 2001).

Wibig, J., Jaczewski, A., Brzoska, B., Konca-Kẹdzierska, K., Pianko-Kluczyńska, K. (2014), How does the areal averaging influence the extremes? The context of gridded observation data sets, Meteorologische Zeitschrift, Vol. 23, No. 2, 181-187, doi:10.1127/0941-2948/2014/0470.

Woyciechowska, J., Ustrnul, Z. (2011), Fuzzy logic circulation types based on the Osuchowska-Klein classification system created for Poland, Theoretical and Applied Climatology 104, 543-549, doi:10.1007/s00704-010-0366-8.

(Received January 22, 2015, revised February 17, 2016, accepted March 11, 2016, Published online March 30, 2016) 